\title{
White, everything white? Josef Frank's Villa Beer (1930) in Vienna, and its materiality in the context of the discourse on 'white cubes'
}

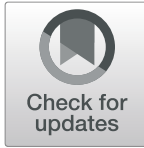

Ivo B. Hammer(i)

\begin{abstract}
In 2017 a group of conservators-restorers conducted a conservation-science study of the materials used in the construction of Josef Frank's main work, the Villa Beer (1930) in Vienna-Hietzing, and of the building's surfaces. The study was an opportunity to find evidence indicating whether the contemporary description of the wall colour as a non-colour white corresponded to physical reality. The notion 'Weiss, alles Weiss' ('white, everything white'), celebrated as 'an expression of values and of the times' (Hammann, 1930), will be identified as a cultural construct that stands in contradiction to the actual materiality of the buildings of the period. We must rewrite the colour history of Modern Movement architecture. The 'White Cubes' were never white.
\end{abstract}

Keywords: Modern movement architecture, Josef Frank, Villa Beer, Materiality, White, Conservation-restoration, Conservation-science study, White cubes, Le Corbusier

\section{Villa Beer: history}

The house of the Jewish family Julius and Margarete Beer, built in Vienna, 13th district (Hietzing), at Wenzgasse 12, designed by Josef Frank and Oskar Wlach in the years 1929-1930, is internationally, alongside the famous buildings of Mies van der Rohe or Le Corbusier, one of the

Correspondence: ivohammer@me.com

HAWK University of Applied Sciences and Art, Hildesheim, Germany

Revised and extended edition of: Hammer, Ivo, 2018. 'Weiß, alles weiß?' Josef Franks Haus Beer (1930) in Wien und seine Materialität im Kontext des Diskurses über die weißen Kuben. In 'VDR Beiträge zur Erhaltung von Kunstund Kulturgut. 8, 106-117; short version: Hammer, Ivo and Robert Linke, 2018. 'White, everything white?' Josef Frank's Villa Beer (1930) in Vienna and its Materiality. In Tostões, Ana and Nataša Koselj, eds. Metamorphosis. The Continuity of Change. Ljubljana, 15th International Docomomo Conference, pp.396-402:; in Slovak language: Biele, všetko biele? Viedenská vila Beer od Josefa Franka (1930) a jej význam v kontexte diskurzu o 'Bielych kockách', in: Archtektúra a Urbanizmus, 2017, Vo. 51, no. 3-4, p. 46-59, including an English abstract. Translation from German, Italian and French literature: Ivo Hammer; referring the term Materiality: see Cerna and Hammer 2008. iconic buildings of the Modern Movement, ${ }^{1}$ 'probably the most important example of Viennese living culture of the interwar period'. (Achleitner 1993, 65-66). It exemplifies the endeavours of Josef Frank, who aimed at 'an independent, enlightened, bourgeois domestic culture, free from stylistic dogmas and fashionable conventions'. His 'Copernican Step in the direction of non-doctrinal, inclusive architecture' (Thun-Hohenstein, Czech and Hackenschmidt 2015, 21) and his understanding of 'the house as path and place' (Frank 1931) was brought to realisation in this house without financial restrictions. The Villa Beer, at first glance, does not seem monumental; it is nevertheless quite an opulent one-family house with 800 square metres of living space (Figs. 1, 2, 3, 4 and 5). Including the basement, it counts 60 rooms on four floors and a mezzanine, the latter dividing the service area horizontally into two spaces with lower ceiling heights. In the spacious living hall, the

\footnotetext{
${ }^{1}$ www.baunetz.de Official website. Alles Frank! Die Villa Beer in Wien, [online] 30.3.2016 [accessed 3 March 2018] Available at: https://www. baunetz.de/meldungen/Meldungen-Die_Villa_Beer_in_Wien_4718353. html
}

Springer Open

(c) The Author(s). 2020 Open Access This article is licensed under a Creative Commons Attribution 4.0 International License, which permits use, sharing, adaptation, distribution and reproduction in any medium or format, as long as you give appropriate credit to the original author(s) and the source, provide a link to the Creative Commons licence, and indicate if changes were made. The images or other third party material in this article are included in the article's Creative Commons licence, unless indicated otherwise in a credit line to the material. If material is not included in the article's Creative Commons licence and your intended use is not permitted by statutory regulation or exceeds the permitted use, you will need to obtain permission directly from the copyright holder. To view a copy of this licence, visit http://creativecommons.org/licenses/by/4.0/. 


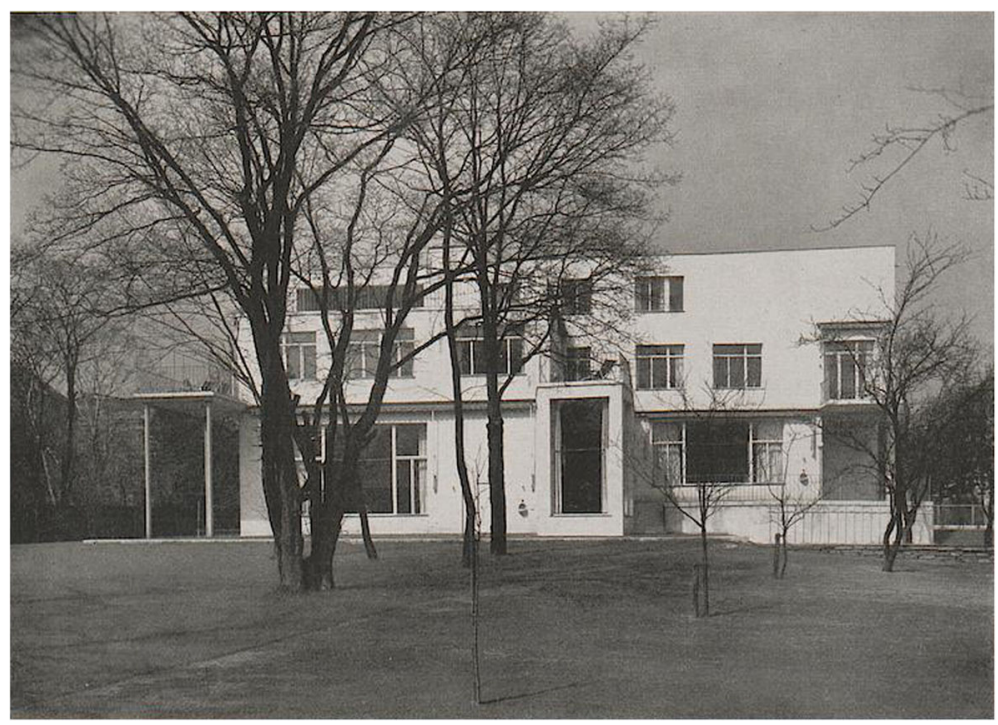

Fig. 1 Josef Frank und Oskar Wlach, Villa Beer, Vienna-Hietzing (1930), east façade (Source: Julius Scherb, Vienna 1931)

mezzanine serves as a music gallery. The lady of the House, Margarete Beer, was a pianist trained at the Viennese music conservatory and friend of Josef Tauber, so her love of music formed thereby a given center for the arrangement (Born 1931, 363; Bojankin 2008, 103).

Josef Frank and his partner, Oskar Wlach, also designed all of the house's interior furniture in every detail: the mobile furnishings, seating, tables, curtains, etc. were manufactured by Haus und Garten (House and Garden), a company founded by the two architects along with Walter Sobotka in 1925 (Ott-Wodni 2015, 195). The house thus represented an artistic synthesis that answered the housing needs of a bygone era. Julius Beer, together with his father Sigmund (1850-1912) and his brother Robert, was manufacturer of rubber products since 1904. From 1920 to 1931 he was managing director of Berson Kautschuk GmbH. In 1930 he had to pledge the house, following a credit agreement with the insurance Allianz and Giselaverein AG including the mobile furnishing (!), with mutual termination waiver until 1937 (Bojankin 2008). Since 1932, lack of money forced him to rent parts of the house. Until 1938 the famous artists Josef Tauber, Jan Kiepura, Marta Eggerth and Marcel Prawy lived in this house. In 1938, the insurance Allianz und Giselaverein $A G$ acquired the house and the mobile equipment by auction. Julius and Margarete Beer had to emigrate to the USA in 1940. In 1941, the textile entrepreneur Hermann 'Harry' Pöschmann acquired the house, from 1946 to 1952 he rented it to the secret service of the British army. The villa

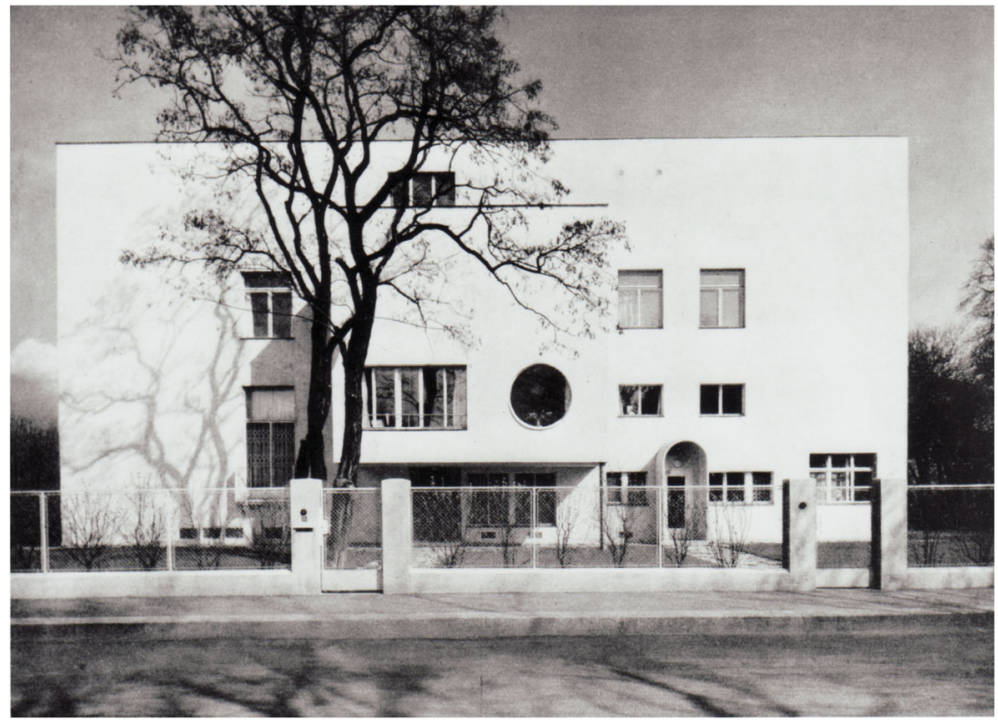

Fig. 2 Villa Beer, Vienna-Hietzing (1930), west façade (Source: Julius Scherb, Vienna 1931) 

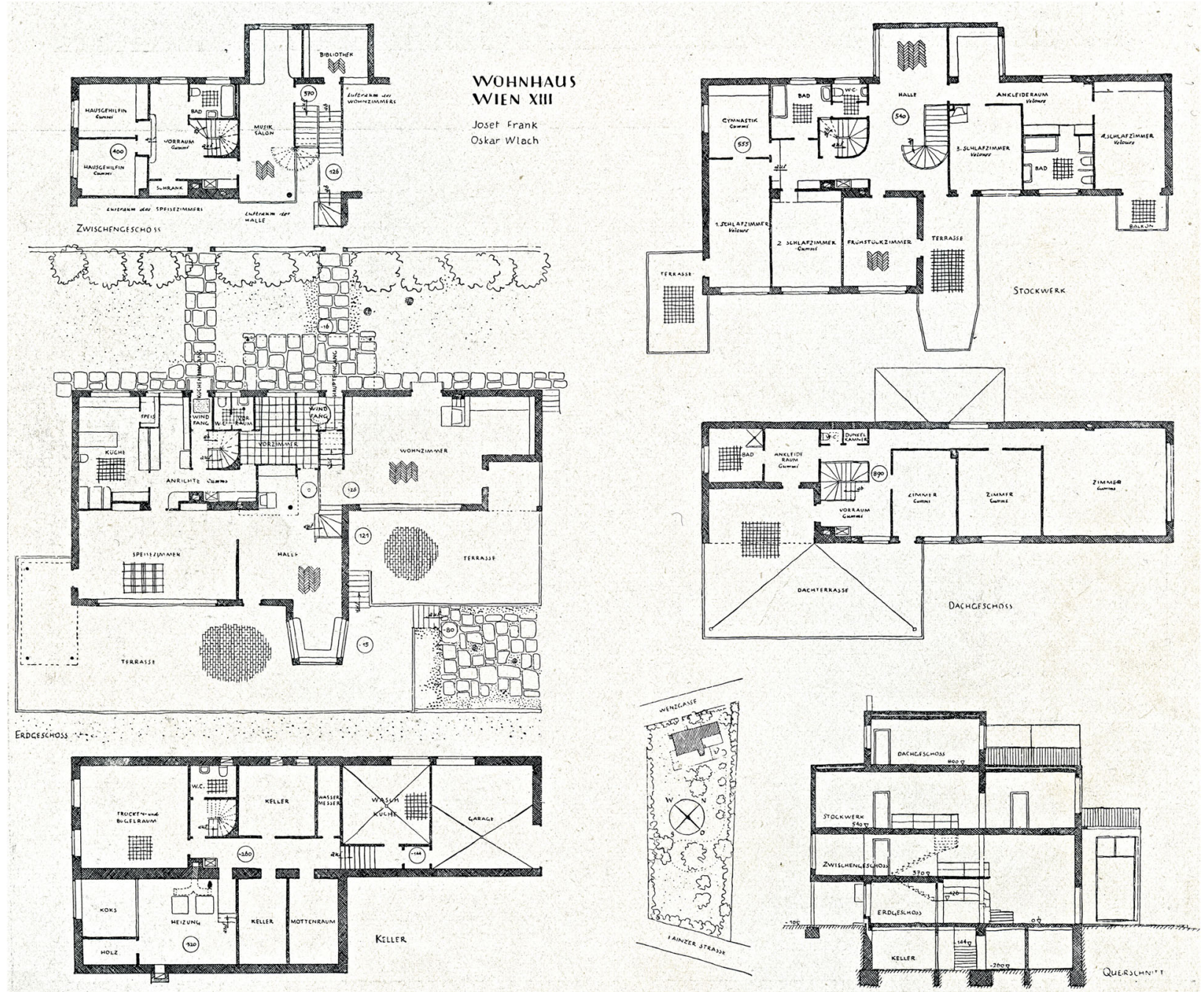

Fig. 3 Villa Beer, Vienna-Hietzing, 1930, publication plans, (Source: Innendekoration 42,1931, 360)

Beer has been divided in the course of its history several times into as many as five apartments. Currently owned by a private foundation, the house will hopefully be acquired by the Austrian state in the near future and made into a museum in its own right, open to the public.

\section{Josef Frank's white}

In 1919, in one of his earliest essays, Josef Frank already wrote about the white colour on the occasion of the walls of his Bunzl House in Pernitz, Austria (1914): 'The walls are white throughout: not only because a colour-intended to dominate the character of a room-makes a very small and scant impression in comparison to the large areas of the outdoor surroundings, but mainly in order to make the occupants feel independent of it and to allow them freedom of choice in everything that they wish to place in their rooms: flowers and paintings, carpets and furniture' (Frank 1919, 410; 2012, 147).
In 1931, Oswald Haerdtl, a student of Frank's, characterized the colour of the walls of Josef Frank's Villa Beer in similar terms: 'The walls of the house, outside and inside, are white. Far from giving a cold impression (sic!), these bright surrounding surfaces, enlivened by floral curtains and oriental rugs, give a sense of serene and light beauty ... The plastered facades are completely white; the window frames and the metal terrace railings are painted in a light greenish gray.' (Haerdtl 1931, 3/43, $48 \mathrm{f}$ and 4/44, 28f). Wolfgang Born, author of a contemporary publication devoted to the Villa Beer, described the colours of the walls in that same year, 1931: 'The coloured impression that this house gives is determined by the pure white of the walls ... '(Born 1931). Josef Frank and his contemporaries primarily understand the term white as the absence, if not independence of colours, as a cultural category, not as a sensual impression that results from the materials used and the structure, texture and facture of the surface. 


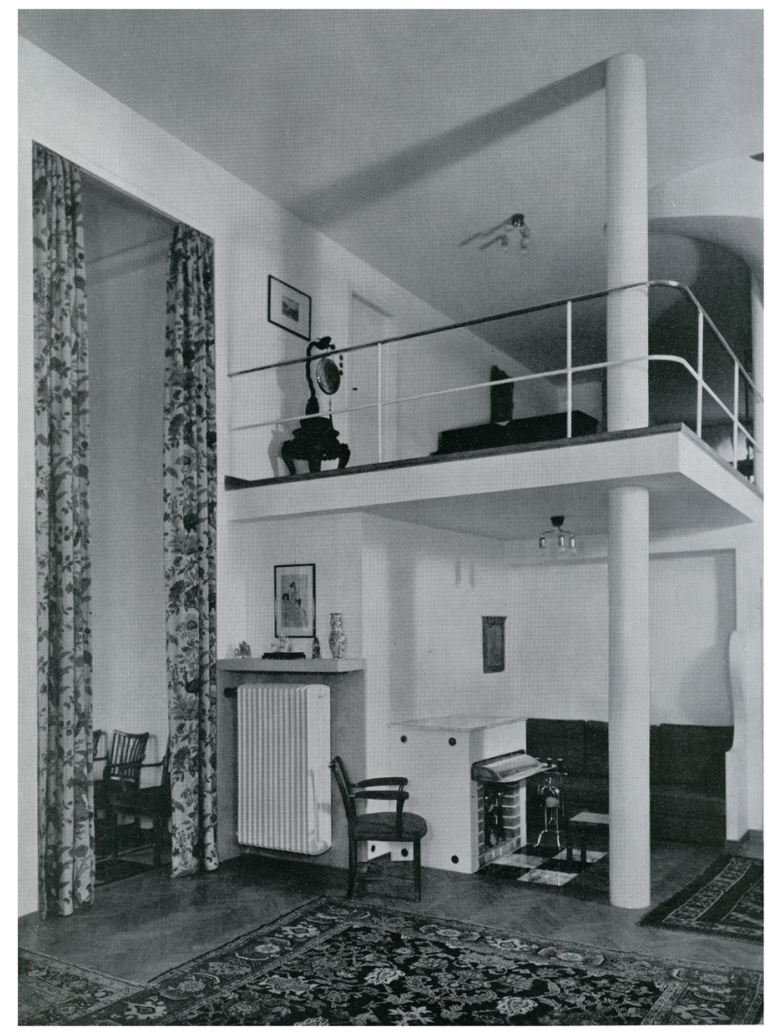

Fig. 4 Villa Beer, Vienna-Hietzing (1930), main hall, view to southwest, including music gallery (Source: Julius Scherb, Vienna 1931)

\section{White as philosophy of live}

In the contemporary discourse on the white of Modern Movement architecture (Gage 1993), J. E. Hammann, in 1930, formulated a pointed opinion in the journal Die Form. For him, the 'colour white' ('der Farbton Weiß') was a metaphor for the spirit of the times ('Zeitgeist'), an important cultural factor, 'a component of today's entire modern philosophy of life' ('Weltanschauung') (Hamman 1930, 122). With regard to the idea behind the white of the interiors, Hammann comes strikingly close to Josef Frank's argument: one seeks to 'gain space' not only 'by means of large windows, gardens adjacent to the house and roof gardens, verandas and the like, but also with the help of the illusion of width created by the white painting. The human being today wants freedom, air and light; he needs distance for his thoughts and ideas' (Hamman 1930).

Le Corbusier, who categorically demanded polychromy and ironically described a whitewashed house as 'pot $\grave{a}$ crème' (Le Corbusier 1926, 146), ${ }^{2}$ valued white as the chromatic complementing element and wrote - following the polemic of Adolf Loos against the ornament: 'If a house is wholly white, the outline of things stands out without the

\footnotetext{
${ }^{24}$ Entièrement blanche la maison serait un pot à crème', Almanach d'architecture moderne, Paris 1926, 146 (I owe the kind references concerning Le Corbusier to Arthur Rüegg)
}

risk of error; the volumes are clearly visible; the colours are unique. The white paint is absolute, everything stands out starkly, like black on white, honest and reliable' (Le Corbusier 1925a, b, 193). Concerning Maison La Roche, 'The interior of a home must be white, but to make this white comfortable, one needs a finely tuned polychrome' (Le Corbusier 1935, 60). ${ }^{3}$ In the polemical article 'Le lait de chauxla loi de Ripolin' in L'art decoratif d'aujourd'hui of 1926, Le Corbusier points out that in all cultures and at all times the lime painting of the houses was customary. For Le Corbusier, the lime as a colour is undoubtedly neutral white, unrelated to actual materiality and colour shading, as he is said to even have ascribed to the white of the façades a leveling effect on class differences in his sentence 'The white of lime is extremely moral' (Tsiomis 2012).

The modern architect Richard Meyer, famous for his white buildings and influenced by Le Corbusier, sees white as an element of design, as a 'neutral surface on which builds the experience of a room. It reinforces the perception of the organisation and order of spatial principles ${ }^{4}$ In the discourse on white architecture since Palladio ${ }^{5}$ and in the famous polychromy-dispute since Winckelmann's supposed white un-colouredness of ancient architecture and classicism, white is thought of as neutral non-colour, as a metaphor, for example, for purity, beauty and sublimity, ${ }^{6}$ but the materiality and colour palette of white, the binders used and surface textures play virtually no role in the discourse (Brinkmann and Scholl 2010).

The architecture of the Modern Movement has become iconically fixed in cultural memory as white architecture due to black-and-white architectural photography, before the general spread of colour photography. As Andreas Haus (2015) suggests, these photographs visually preserve not only the design but also 'the utopian and socially romantic

\footnotetext{
${ }^{3}$ Dans l'ambiance de blanc cru [sic], les couleurs surnommées prennent une signification intense, qualifiée, précise: ce sont des caractères, elles deviennent des caractères'. In: Rüegg 2015, 100

${ }^{4}$ Meyer, Richard, quoted by Philipp, Klaus Jan and Stemshorn, Max (eds.), The Colour White: Colour Rush and Colour Dropout in Architecture, Berlin 2003. Meyer's beautiful townhouse in Ulm is coated with an ubiquitous and banal synthetic resin paint containing titanium white on a 'full thermal insulation' clad ('Vollwärmeschutz') ${ }^{5}$ Andrea Palladio, Die vier Bücher zur Architektur, I quattro libri dell architettura (Italian-German), Translated from the Italian and introduced by Hans-Karl Lücke, Wiesbaden 2008. 'Von allen Farben passt keine so gut zu den Tempeln, wie das Weiß, da die Reinheit dieser Farbe und die Reinheit des menschlichen Lebens in höchstem Maß Gott angemessen ist.' (Of all the colours, none suits the temples as well as the white, because the purity of this colour and the purity of human life are most appropriate to God; translation: I.H.), http://www.maehlmann. com/architektur/palladio (accessed 25.5.2018)

${ }^{6}$ Johann Joachim Winckelmann, Geschichte der Kunst des Altertums, Dresden 1764; http://digi.ub.uni-heidelberg.de/diglit/ winckelmann1764/0001/image; Raulet, Gérard (ed.), Von der Rhetorik zur Ästhetik. Studien zur Entstehung der modernen Ästhetik im 18. Jahrhundert, Paris 1995
} 


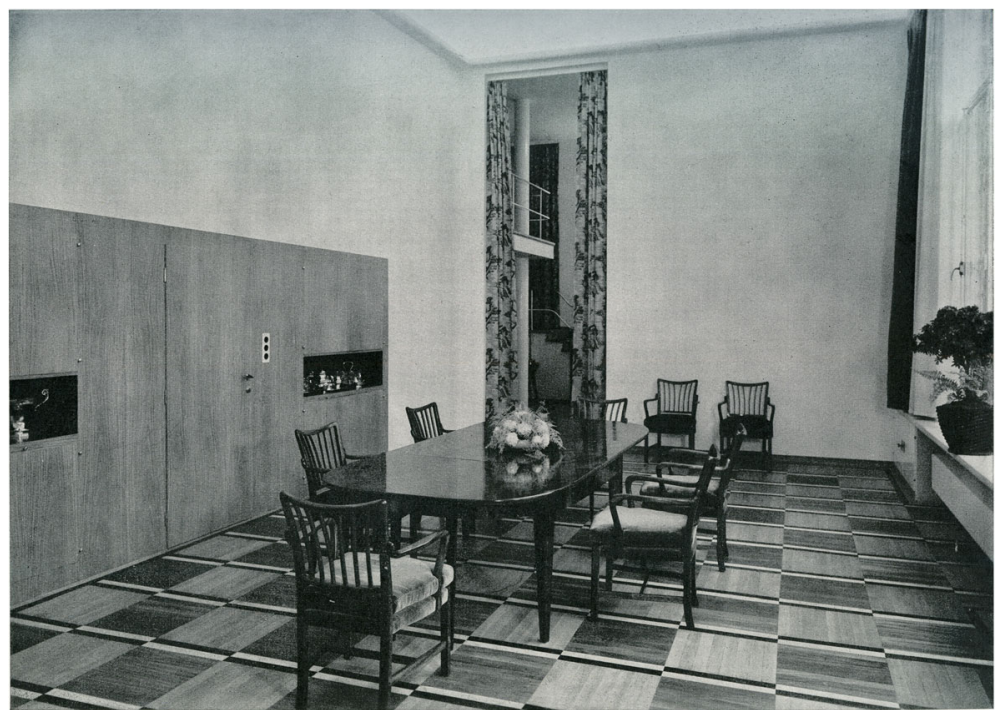

Fig. 5 Villa Beer, Vienna-Hietzing (1930), dining room, view to the north side; the wall show some irregularities, perhaps due to the facture (Source: Julius Scherb, Vienna 1931)

ideas of the early post-war period and develop them with photographic perfection'.

However, the photographs are not only media and projection surfaces for a cultural construct, but they are also actively involved in the production of these ideas: The Brno photographer Rudolf de Sandalo (1899-1960) has made characteristic retouching in his photos of the Tugendhat house commissioned by Ludwig Mies van der Rohe. These retouching dampen light phenomena, especially shadows and irregularities, which could give hints to the materiality of the surface and could disturb the continuum of the surface. By means of retouching, the photographer has even eliminated traces of aging and construction errors like cracks. Even today, the photographs of the Tugendhat house by Thomas Ruff (1999-2001) with bright white facades bring about a similar de-historicisation (Hammer 2004, 14). (Figs. 6 and 7).

\section{Destructive prejudices}

Until 20 years ago, the stereotypical idea of white architecture for the period continued to prevail even in the case of the façades of the masters' houses in Dessau, which had been inhabited by Feininger, Kandinsky and Klee. The authorities and architects opted against carrying out a conservation-science study and thus conceded the possible destruction of the original polychrome (Danzl 2003, 154).

The prevalent idea of 'White Cubes' for the 1920s and 1930s has also had consequences with respect to

\footnotetext{
${ }^{7}$ The term white cube, which is often used in connection with Modern Movement architecture, is probably not contemporary; he probably goes back to the essay collection of Brian O'Doherty, Inside the White Cube. The Ideology of the Gallery Space, San Francisco 1976.
}

preservation practices, both past and present: without regard to the original material composition of the surfaces, façades of the Modern Movement era have been repainted in a garish white using such modern, non-compatible materials as titanium white and artificial resin (Hammer 2003). (Figure 14) More often than not, the original plaster surfaces of the façade and the interior walls have been destroyed, because many professionals perceive them as interchangeable garments (Metzger-Szmuk 2008).

The heritage inspectors often are more concerned with the colour hues of a polychrome façade, with unintentional humour called 'Schauwert' (show value), than with the authentic materiality.

\section{Coloured white \\ Awareness and studies}

In the last 15-20 years, conservators/restorers have carried out conservation-science studies of the Bauhaus (19992000) $\left(\right.$ Danzl 1999, 2003) ${ }^{8}$ (Fig. 13), for example, and of the Weissenhofsiedlung in Stuttgart (2002-2005) (Reichwald 2008), the Tugendhat House (2003-2005) (Hammer 2014) (Figs. 8, 9, 10, 11 and 12) and Maison La Roche (2008)

\footnotetext{
${ }^{8}$ The official website of the Bauhaus Dessau apostrophises the buildings until today as white cubic structures https://www.bauhaus-dessau.de/ unesco-weltkulturerbe1.html (access 16.5.2018). Jacques Sbriglio spoke at the colloquium 'Le Corbusier. L'oeuvre à l'épreuve de sa restauration' 2015 in Paris, calling earlier restorations an 'iconoclastic' approach.https://www. canal-u.tv/video/institut_national_de_1_histoire_de_1_art/

colloque_le_corbusier_l_oeuvre_a_l_epreuve_de_sa_restauration_1 _2.18323 (I owe that information to conservatrice-restauratrice Ariel Bertrand)

${ }^{9}$ Probes by conservatrice-restauratrice Ariel Bertrand, 2008; PierreAntoine Gatier, Restoration of the Maison La Roche, http://www.fondationlecorbusier.fr/ (2009) (access 26.9.2018)
} 


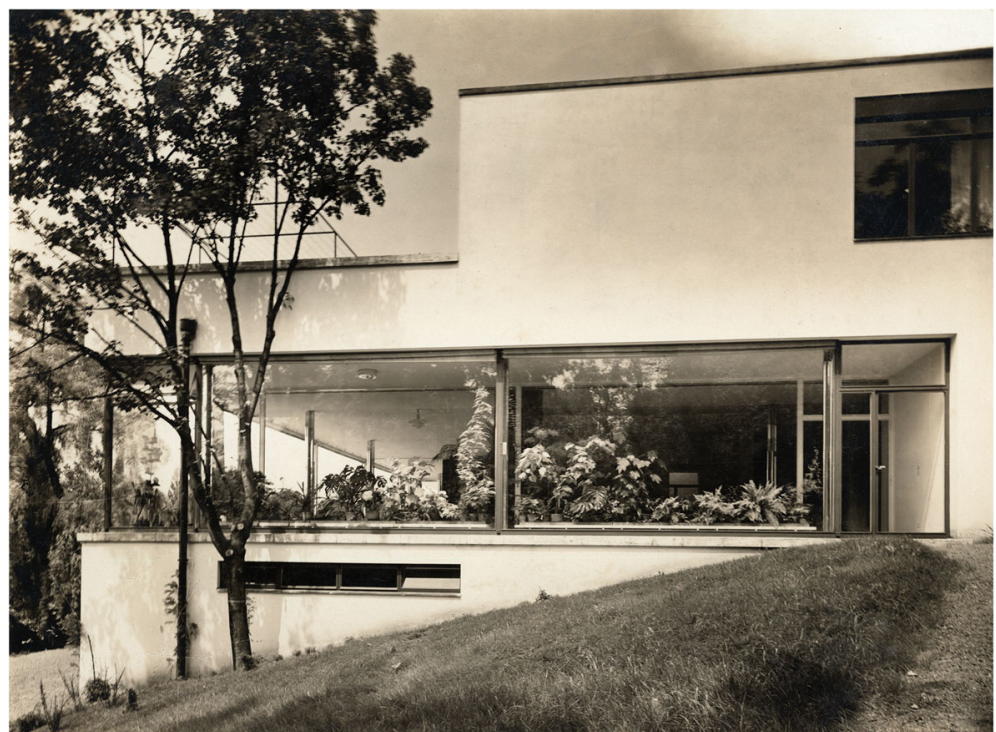

Fig. 6 Ludwig Mies van der Rohe and Lilly Reich, Tugendhat House, Brno 1930, south-east-facade; The photo has been retouched to eliminate elements of the facture and aging on the plaster surface (Source: Rudolf de Sandalo, Brno 1931)

(Fig. 15). These studies have shown that the stereotypical idea of white cubes has a relation to a culturally constructed category but does not correspond to physical reality. The white cubes, for the most parts were plastered with lime mortar and mostly painted with lime wash containing polychrome silicic aggregates for technical reasons (which is explained in more detail below).

The authors of the landmark exhibition The International Style at MoMA, New York in 1932, already pointed to the materiality of the surfaces, which was forgotten for a long time in the following discourse despite the so called material turn (Strässle et al. 2013): 'The ubiquitous stucco, which still serves as the hall-mark of the contemporary style, has the aethetic advantage of forming a continuous even covering' (Hitchcock and Johnson 1932, 50). With reference to Le Corbusier's double-house in the Weissenhofsiedlung in Stuttgart (1927) they state:' ... the majority of wall surfaces remained white'. With a sensitivity that we now perceive as extraordinary, they also discuss the colour shade of white as a material colour: 'The colour of natural surfacing materials and the natural

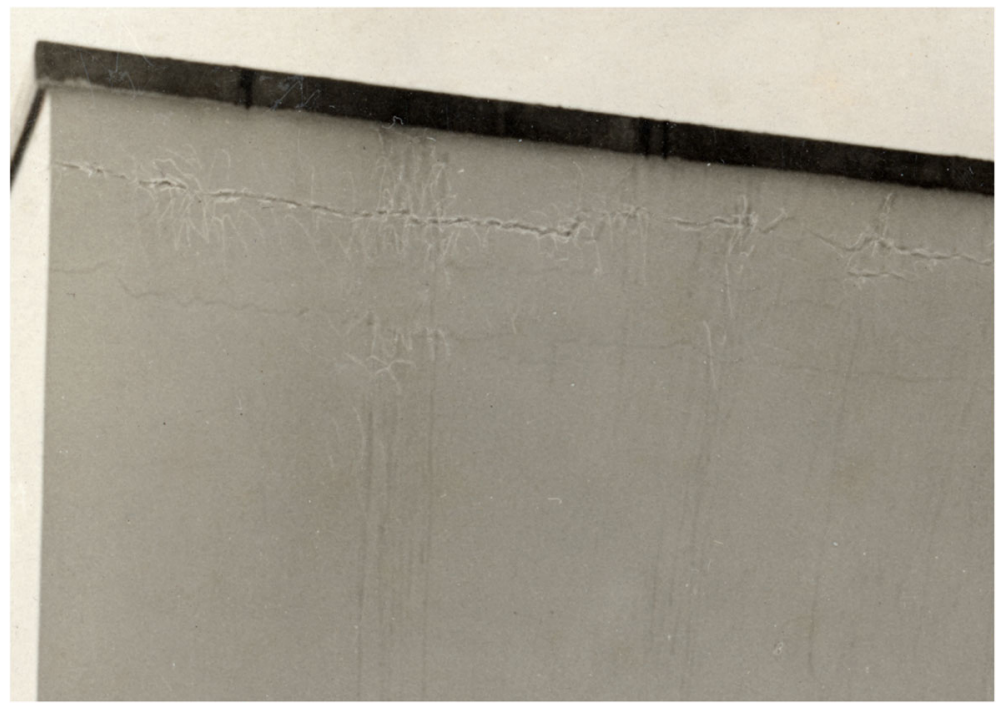

Fig. 7 Tugendhat House, Brno 1930, south east wall of Grete Tugendhat's dormitory, detail: the crack between concrete roof and the brick wall, a deficiency in the construction, has been retouched (Source: Rudolf de Sandalo, Brno 1931, detail) 


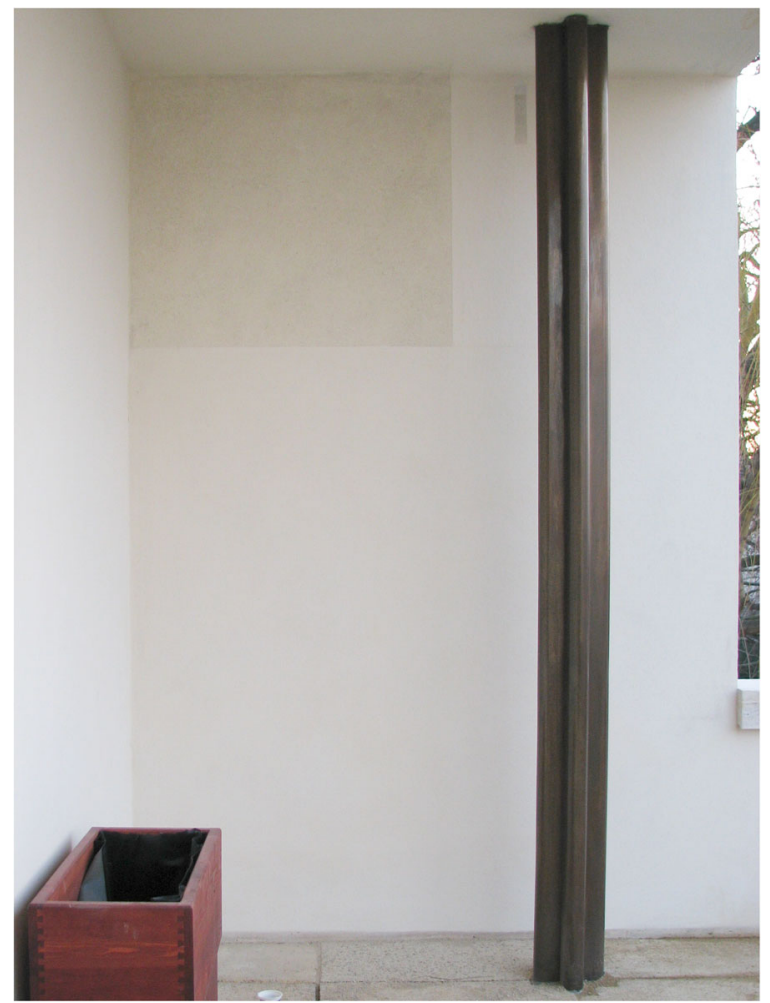

Fig. 8 Ludwig Mies van der Rohe and Lilly Reich, Tugendhat House, Brno (1930), upper terrace, view to the southeast: 'Archaeological window' (campione), which shows the original facade surface. The lime wash of the remaining façade surface, re-established according to the historic tradition of repair and renewal, is kept lighter because it darkens as it ages (Source: Ivo Hammer 2012)

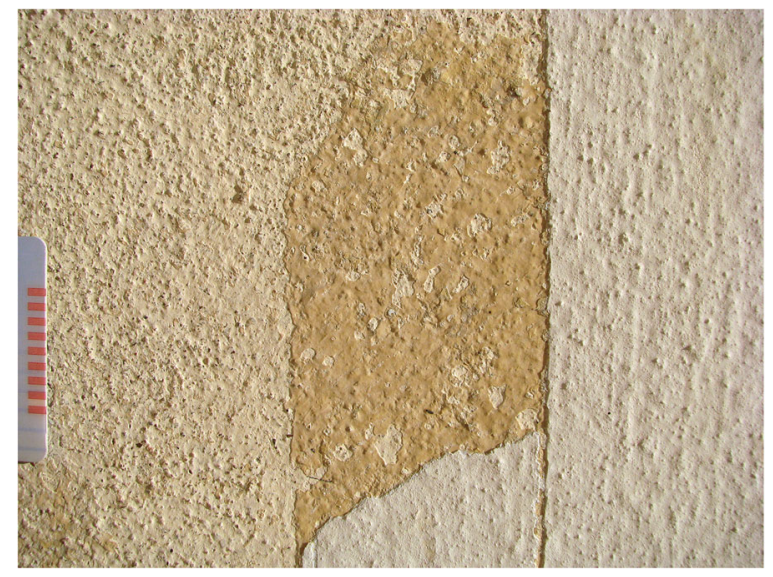

Fig. 9 Tugendhat House, Brno, 1930, view to the southeast, detail: probe during the removal of the later plasterings (from right to left): painting of 1985 (with cement and synthetic resin), two lime coats (between 1945 and 1965), heavily sulfated due to air pollution, and original surface with yellowish whitewash (picture lower edge approx. $17 \mathrm{~cm}$ ) (Source: Ivo Hammer 2011) metal colour of detail is definitely preferred. Where the metal is painted, a dark neutral tone minimizes the apparent weight of the window frame. In surfaces of stucco, white or off-white, even where it is obtained with paint, is felt to constitute the natural colour' (Hitchcock and Johnson 1932, 75-76).

Before the building materials companies and their laboratories in the 1960s began to market finished products with retorted 'modified' and 'optimized' materials that could be processed quickly and without special craftsmanship the craft precision was a more or less natural part of building (Hammer 2003). With the abolition of ornamentation and ornamental structuring of the surface in Modern Movement architecture, even the demands on craftsmanship increased. Coating an undecorated wall with traditional 'impeccable' techniques is, as Otto Rückert notes in Die Form 1931, a much more difficult task than a wall 'structured by pilasters and divided into fillings' (Rückert 1931). In view of the real conditions of building production, the goal of 'machine aesthetics' could only be achieved with routine and precise craftsmanship (Wagner 2008,2018 ). And yet you can see in historical photographs - also in technical print reproduction - a certain liveliness of the surfaces, irregularities that are to be interpreted as traces of the manual production, called facture, and-what is often forgotten-the natural aging. ${ }^{10}$

\section{Lime surfaces: historic technology}

The findings of conservators-restorers obtained in conservation-science studies of the 'white' façades of Modern Movement architecture are different with regard to many technological parameters, for example with regard to the sands used (which partly also depends on the region), to hydraulic proportion of the lime mortar, the layer structure and the surface texture. But they have something in common: they were never pure white, the whiteness of the lime was always "broken." ${ }^{11}$ (Figs. 8, 9, $10,11,12,13,14,15$ and 17a).

\footnotetext{
${ }^{10}$ Hitchcock and Johnson (1931), e.g. p. 111, Le Corbusier (Maison Savoye, 1930, natural, non-painted plaster; p. 115 Weißenhofsiedlung, 1927; p. 117 (Maison Stein 1928); p. 133, Otto Eisler (Brno, doublehouse 1926); p. 149, Max Ernst Haefeli (row house, Zürich 1929); p. 151, Otto Haesler (KURZAG, Bruns- wick 1930)

${ }^{11}$ As part of a research project of the HAWK Hildesheim under the direction of Ivo Hammer, the facade plasters of a number of Modern Movement buildings were examined: Berlin, Grellstraße, Bruno Taut Siedlung (1927), 1998; Dessau, Bauhaus, Preller House (1926), 2000; Brno / CZ, House Tugendhat (1930), 2003-2010; 2005:

Complementary studies on the craftsmanship tradition in Brno, fair grounds, buildings of the 1928 anniversary exhibition: Emil Králík, Pavel Janák, Josef Gočár (2005); 2004: Buildings by Ludwig Mies van der Rohe during the Berlin period, the houses Riehl (1907/1910), Perls (1911), Werner (1913), Urbig (1915), Mosler (1924), Eichstädt (1921/ 22), apartments for rent in Afrikanische Strasse (1926), Lehmke (1932); HAMMER 2014, $252 \mathrm{~s}$.
} 

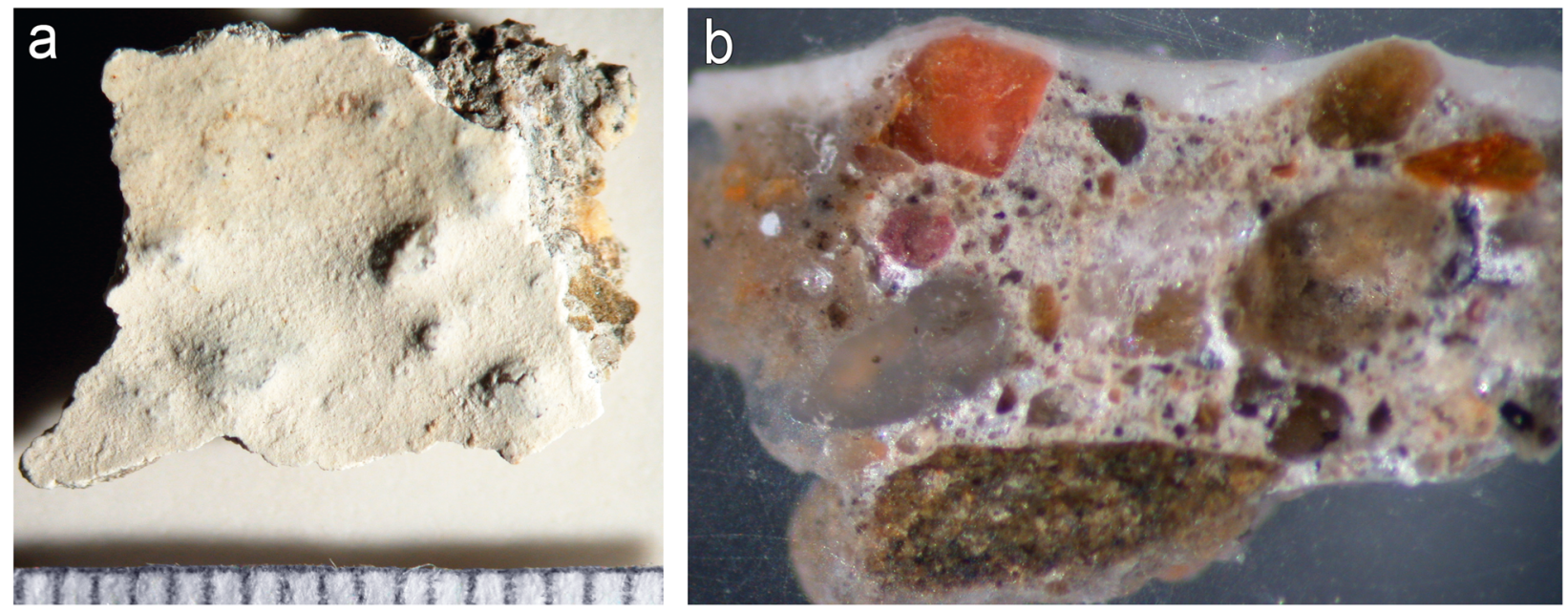

Fig. 10 Tugendhat House, Brno, 1930, samples of the façade plaster. a: macro shot of the original surface of the facade plaster, picture lower edge $13 \mathrm{~mm}$. b: polished section of the facade plaster (Source: study work HAWK / Hildesheim, Ivo Hammer and Christine Hitzler 2004)

In general, one can assume the following essential technical factors for the brightly coloured, often purely white lime coatings of facades, including Modern movement architecture: The (slightly hydraulic) lime mortars were usually mixed at the construction site. The sands were mostly not washed. The washing of the mortar sand began on a grand scale only after the Second World War, with the disappearance of traditional calcareous technology and the victory of (armored) concrete technology. The fine silicates contained in the pigments or the sands, i.e. silt grains of the order of grain size of about 2-

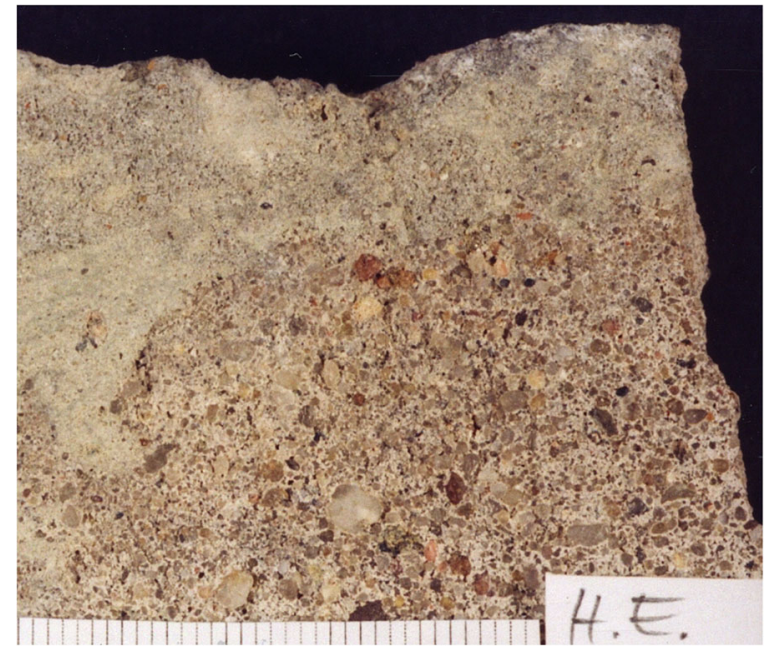

Fig. 11 Ludwig Mies van der Rohe, Berlin Nicolassee,

Dreilindenstraße 30, Haus Eichstaedt (1921-1923), plaster sample: rubbed reddish-yellow plaster (with brick fragments and partially preserved patina) (Source: study work HAWK / Hildesheim, Ivo Hammer, Stefanie Dannenfeldt, Vanessa Knappe, Natalie Schaack)
$63 \mu \mathrm{m}$, not only have a colouring effect, but also a hydraulic effect in the reaction with the hydrated lime. As the laboratory analysis by Hubert Paschinger shows, 'dry-slaking', i.e. mixing the fresh lime with the sand before slaking it, promotes the reaction (Hammer 2008) (Fig. 16). As long as the clayish portion of the sand is not too high, it results in a high quality of the lime plaster even without additional hydraulic aggregate.

The facade paintings of the Modern Movement architecture are usually consisting of slaked lime. For technical reasons, it is not appropriate to paint a pure whitewash of hydrated lime on the set, 'dry' plaster of a facade, it would not crystallize properly and would not withstand weathering. It is traditional practice to mix the lime wash of a facade with very fine (unwashed) sand in silt size and, in addition, if necessary, mineral pigments (Hammer 2011). ${ }^{12}$ The 'breaking' or 'tuning' of paints by admixing complementary pigments belongs, as I know from experience, to the craft tradition of a painter familiar with historical techniques. In addition, the fine silicates apparently also accelerate the formation of calcite crystals (Hammer 2010), thus the binding of the hydrated lime by absorption of $\mathrm{CO}_{2}$. Only a lime wash applied in fresco technique, thus in the fresh lime plaster, can show a radiant white in the fresh condition. However, by the aging and with it by the change of the crystal structure it becomes yellowish.

\footnotetext{
${ }^{12}$ The limewash of the interior of the St. Marien church in Salzwedel was pigmented with sand slurry, following the technology I developed on site according to craft tradition and results of laboratory analysis The limewash was smudge-resistant approx. $4 \mathrm{~h}$ after painting
} 


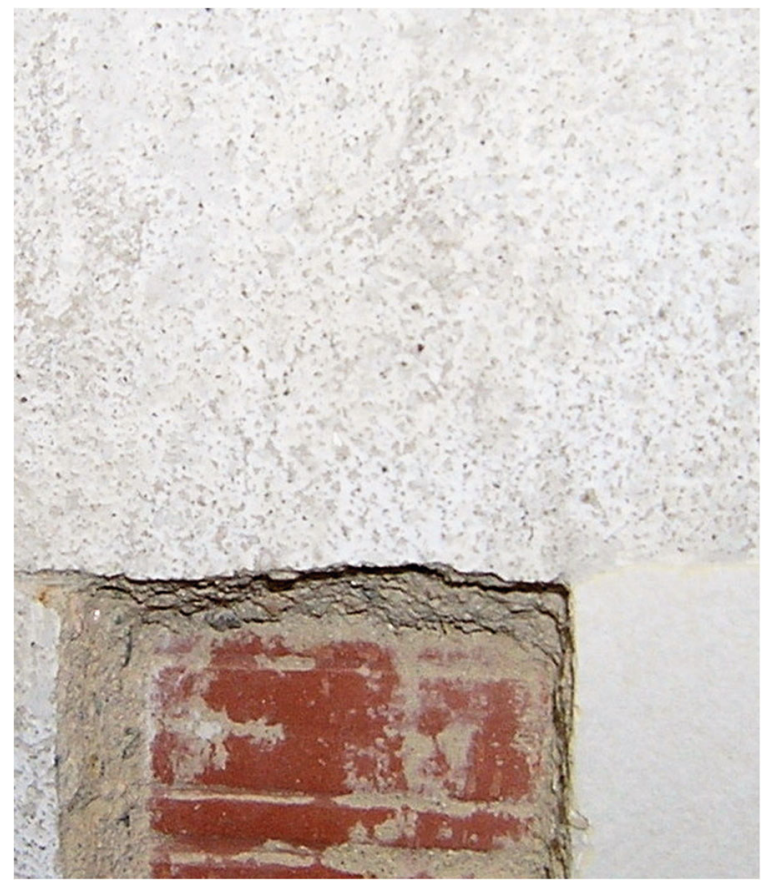

Fig. 12 Pavel Janák, Brno, fair grounds, pavilion of the Prague School of Applied Arts, 1928, original facade plaster: the surface rubbed, with thin, bright fresco-lime wash, similar to the later one at the house Tugendhat (Source: study work HAWK / Hildesheim, Ivo Hammer, Silke Heinemann and Jan G. Menath, 2005)

Pure lime washes (without organic binders) on already hardened plaster of facades can therefore not be completely white for technical reasons; the lime whiteness is always tinted by the fine silicates of a sand, mostly created by a fine slurry of non-washed sand.

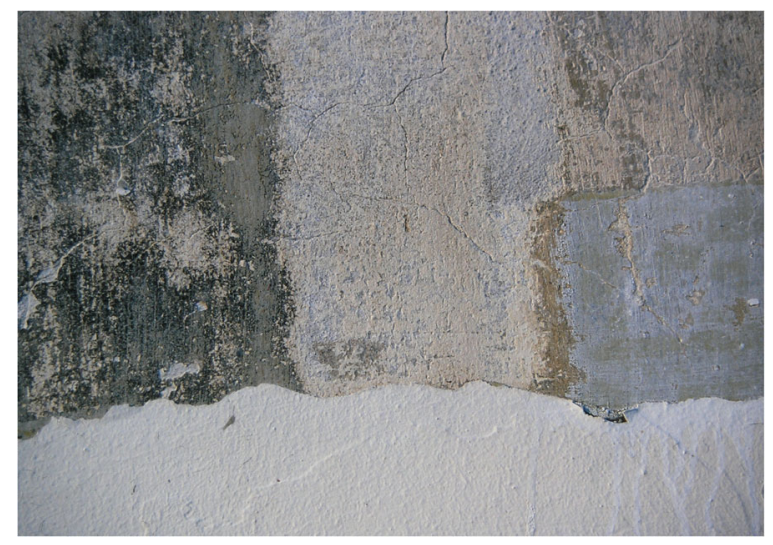

Fig. 13 Walter Gropius, Dessau, Bauhaus, Prellerhaus, 1926, east facade, detail, samples for the removal of later coatings; on the smoothed reddish-yellowish plaster (early shrinkage cracks!) lies a thin lime wash of the same colour, probably dyed with silicate sand fines. The surface is patinated and also sulfated (Source: Analysis Nils Mainusch, HAWK / Hildesheim, 2000)

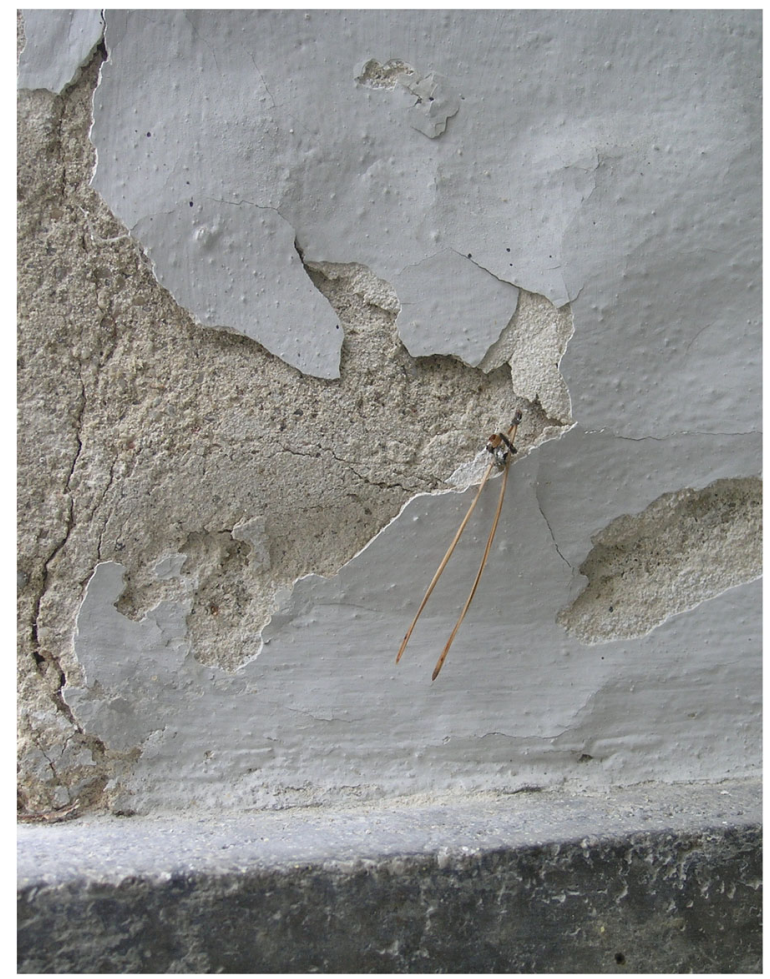

Fig. 14 Dessau, master house Klee / Kandinsky, 1926; the original material-coloured smoothed plaster appears under the recent titanium-white coating, possibly containing a synthetic resin component, in 2006 (Source: Ivo Hammer)

The garish whiteness of the titanium dioxidecontaining paints of the past decades are neither technically nor aesthetically pleasing. They fit to the critical words of Hitchcock and Johnson of 1932 regarding bright colours: If architecture is not to resemble

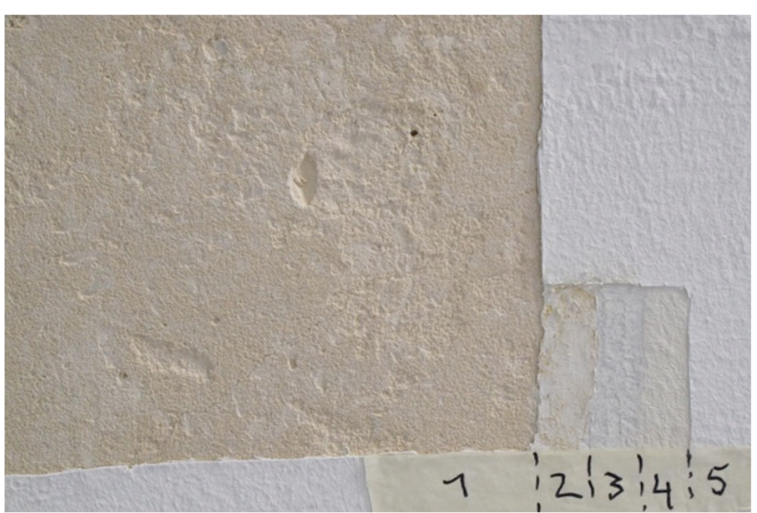

Fig. 15 Le Corbusier, Paris, Maisons La Roche-Jeanneret (double-house), Square du Docteur-Blanche in Paris (1923), 2008-2009 Restoration campaign led by architect Pierre-Antoine Gatier, probe: Ariel Bertrand. The main facade consists of a smoothed natural plaster of yellowish limestone, lime and white cement (?); the surface of the plaster shows that the surface is darker than the mortar matrix, probably due to sulfatation and sintering (Source: Ariel Bertrand, Paris 2008) 


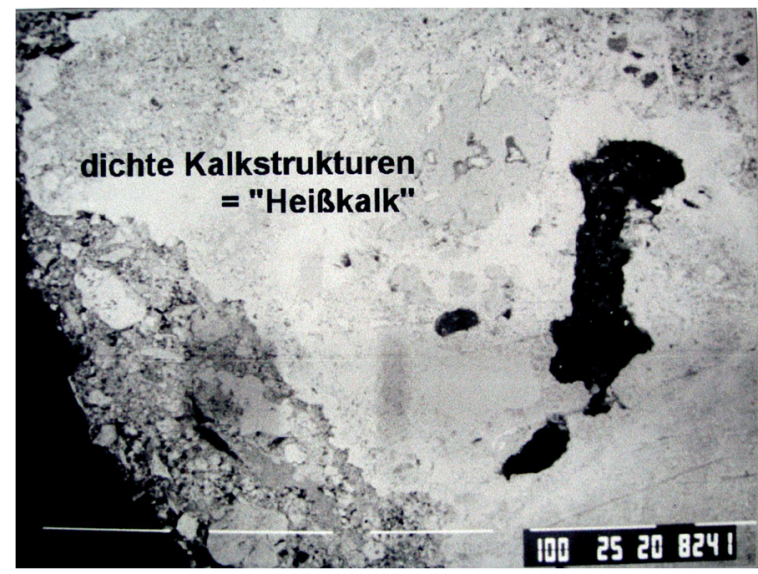

Fig. 16 Bratislava, castle, wall painting fragment of Regnum Maravorum (B1), 2nd half of the ninth century; favored by 'dryslaking' (i.e. the mixture of non-washed sand and fresh lime before slaking), the fine silicates cause hydraulic reactions; analysis Hubert Paschinger, Federal Heritage Office, Vienna, No. 1240/98 (Source: Hammer 2008,122)

billboards, colour should be both technically and psychologically permanent' (Hitchcock and Johnson 1932, 76).

With increasing knowledge of the materiality of the facade surfaces of the Neues Bauen, one has to correct the idea of the white cubes, which is anchored in the cultural memory, with regard to the concrete structures: the 'white cubes' were never white.

Even in the buildings of those architects who abstained from the use of chromatic colour in the architectural surface, such as Ludwig Mies van der Rohe and Josef Frank, the bright tones are the product of coloured material. The floating, immaterial 'white screens' of the facades ('... volume is felt as immaterial and weightless, a geometrical bounded space ... like a skin tightly stretched over the supporting skeleton ... screen walls ... ') (Hitchcock and Johnson 1932, 44), which on the aesthetic level want to raise the principle of mass and heaviness, the aim formulated by the Dutch protagonist J. J. Pieter Oud as 'abstraction of the material appearance' of the surfaces (Haus 2015, 186) are made of heavy material. The traces of craftsmanship, the facture, i.e. the unevenness of the wall, the irregular, lively application of the whitewash, the scaffolding boundaries, the traces of aging and weathering, are visible not only in the tangible buildings, but also in the black and white photographs (Fig. 17a), even if the photographers partially retouched these traces. Aging of a lime wash also means that the binder becomes more yellowish, either by the enlargement of the lime crystals in the sintering process, either by incrustation or by gypsum, and that the weathering also leads to gradual loss of substance. The aesthetics of the surface also include the aesthetic consequences of the tradition of periodic repair by means of materialcompatible interventions or the renewal of the lime paint. The re-establishment of the historic tradition of repair and renewal of facades using a lime wash shouldn't be misunderstood as 'sacrificial layer' (Koller 1989; Dai and Zhong 2019). The traditional periodic repair and renewal using a lime wash is an intrinsic element of the authentic materiality and appearance of historic architecture (Hammer 2003).
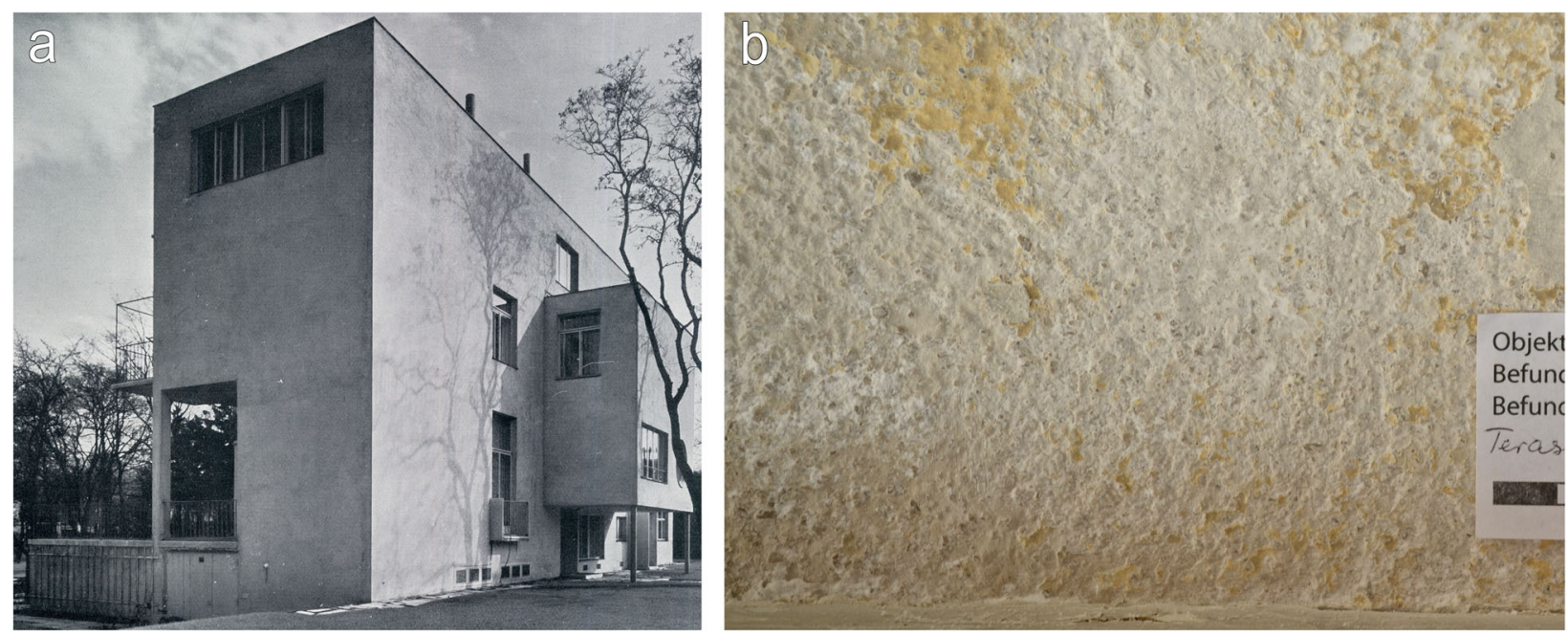

Fig. 17 Josef Frank and Oskar Wlach, House Beer in Vienna-Hietzing, 1930. a: from northwest. On the northern façade, the traces of the facture can be seen: scaffolding borders, irregularities [Source: Julius Scherb, Vienna 1931). b: roof terrace, sunbathing niche, ceiling, original façade surface with remnants of four later overcoats and salt efflorescence, yellowish lime wash pigmented with fine silicates on grated lime plaster (Source: HABEAS 2017) 


\section{Villa beer materiality}

\section{Conservation-science study $(2017)^{13}$}

The primary objective of the conservation-science study, called HABEAS, carried out by a group of conservators-restorers in 2017 under the direction of Ivo Hammer, was to conduct a pilot survey of the wall surfaces with respect to heritage conservation and to establish short-term orientation for the redevelopment of this private property as a state museum. ${ }^{14}$ Only four days were available for on-site examination. The client's basic idea was, while limiting intervention to a minimum, to carry out the conservation/restoration of the house and to adapt it step by step to the needs of a museum-a 'work in progress', so to speak. Apart from the analysis of materials, wall surfaces, ceilings, floors and built-in furniture, the research team also concerned itself with the need to calculate structural measures in terms of building security, fire protection, heating, electrical installations, sanitary facilities and adaptations necessary for the house's operation as a museum. ${ }^{15}$ The conservators/restorers implemented their transdisciplinary research in collaboration with experts from the Federal Heritage Authority (DI Dr. Robert Linke, scientific research, ${ }^{16}$ and DI Oliver Schreiber, responsible consultant), with the architect Mag. Claudia Cavallar and other professionals (building equipment, appliances). Very helpful were the researches of Johanna Wilk from 2012 on the interior of the villa Beer (Wilk 2015). The study documentation included room data sheets (collectively 'Raumbuch' in German) for the 60 rooms of the house.

\footnotetext{
${ }^{13}$ In accordance with the owner, the Dr. Johannes Strohmeyer Private Foundation, Commissioned by the MAK - Museum of Applied Arts, Vienna: Dr. Christoph Thun-Hohenstein, Mag. Teresa MitterlehnerMarchesani, Mag. Martina Kandeler-Fritsch, Dr. Sebastian Hackenschmidt (contact), Herbert Obermaisser; Hammer, Ivo, 'Aide mémoire' reporting a conversation with MAK, ms. 17.12.2016

${ }^{14}$ Survey on site 24.- 27.1.2017; participants: academic conservators/ restorers Ivo Hammer (director), Alexandra Sagmeister, Lea Huck, Magdalena Schindler, Susanne Wutzig, an inspiring team; architect: Claudia Cavallar (construction files, plans, historical photographs); heritage authority: Oliver Schreiber, Robert Linke (laboratory analysis); Preliminary report: 13.2.2017; report on the pilot survey: 1.8.2017. We acknowledge the permission given by Tano Bojankin to document his private rooms in the Villa Beer

${ }^{15}$ Commissioned by the MAK, a planning phase concerning, as mentioned, structural measures and calculation took place in the second half of 2017, executed by Ing. Dr. h.c. Erwin Resetarits and Mag. Claudia Cavallar. The conservators/restorers were not involved in the planning - as usual in the field of preservation of historic architecture, but nevertheless questionable from the methodological point of view

${ }^{16}$ Microsamples embedded in acrylic resin, section grounded, imaging using light and UV-fluorescence microscope, SEM, ultrathin coating with gold, material analysis using EDX, indication of animal glue using fuchsin
}

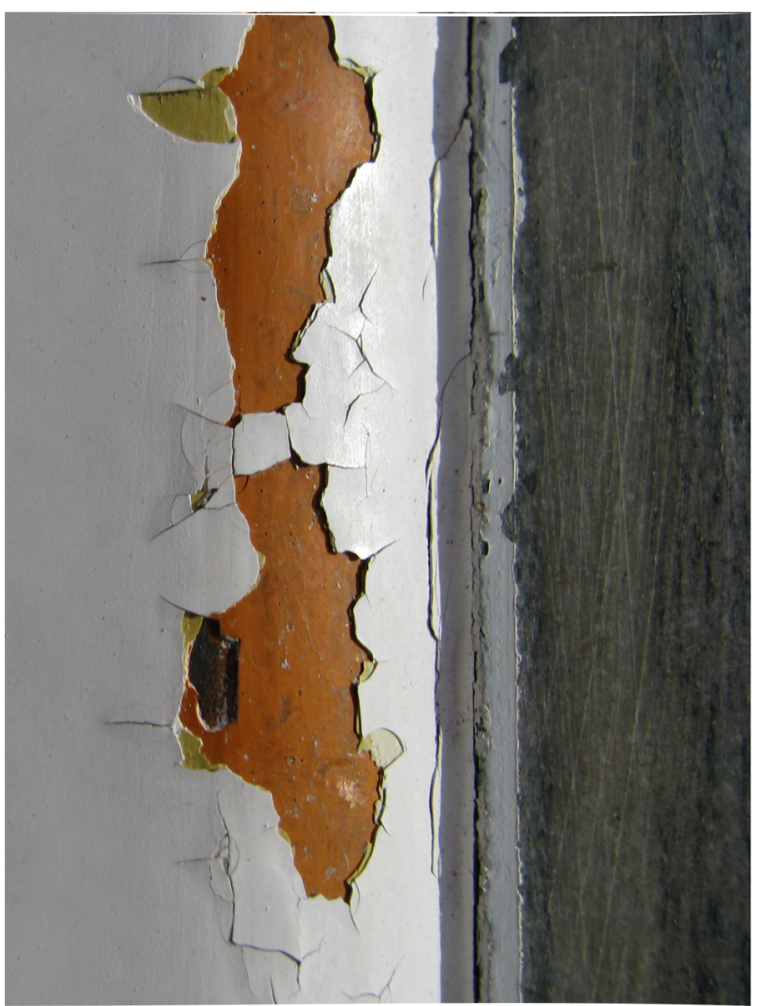

Fig. 18 Josef Frank and Oskar Wlach, Villa Beer in Vienna-Hietzing (1930), west facade, main entrance, metal door frame, detail with remains of the original 'Japanese red' paint (Source: Ivo

Hammer 2017)

\section{Façade}

The fine plaster, with a grain size of about $0-2 \mathrm{~mm}$, was found to have been rubbed and smoothed with a wooden board to create a rough surface. ${ }^{17}$ The yellowish-white whitewash, probably pigmented with fine grains of sand, is so thin that it barely covers the grains, ${ }^{18}$ a finding that can be compared with accuracy to those concerning the façade plaster of the Tugendhat House in terms of structure, texture, facture and, above all, the shade of white (Hammer 2012, Hammer 2014, 183). The varnish of the exterior window frames, the railings of the terraces and most of the metal doors are also in line with the achromatic 'colourfulness' of the render of the façade: a very slightly greenish grey, a multi-layered

\footnotetext{
${ }^{17}$ The traditional bricks walled with lime mortar, stiffened at static critical points with lime-cement mortar, stamped concrete and partially reinforced concrete. Thickness of the wall: $38 \mathrm{~cm}$

${ }^{18}$ Seebach, Gerhard, Untersuchungsbericht zum Fassadenputz, Mai 1999, files of the Bundesdenkmalamt (Austrian Heritage Office). Well preserved parts of the exterior plaster can be found on the upper terrace which has been partially transformed into an interior. The façade was renovated with a pre-fabricated mortar and silicate-resin paint containing titan white (KEIM Organosilikat) in 2015
} 

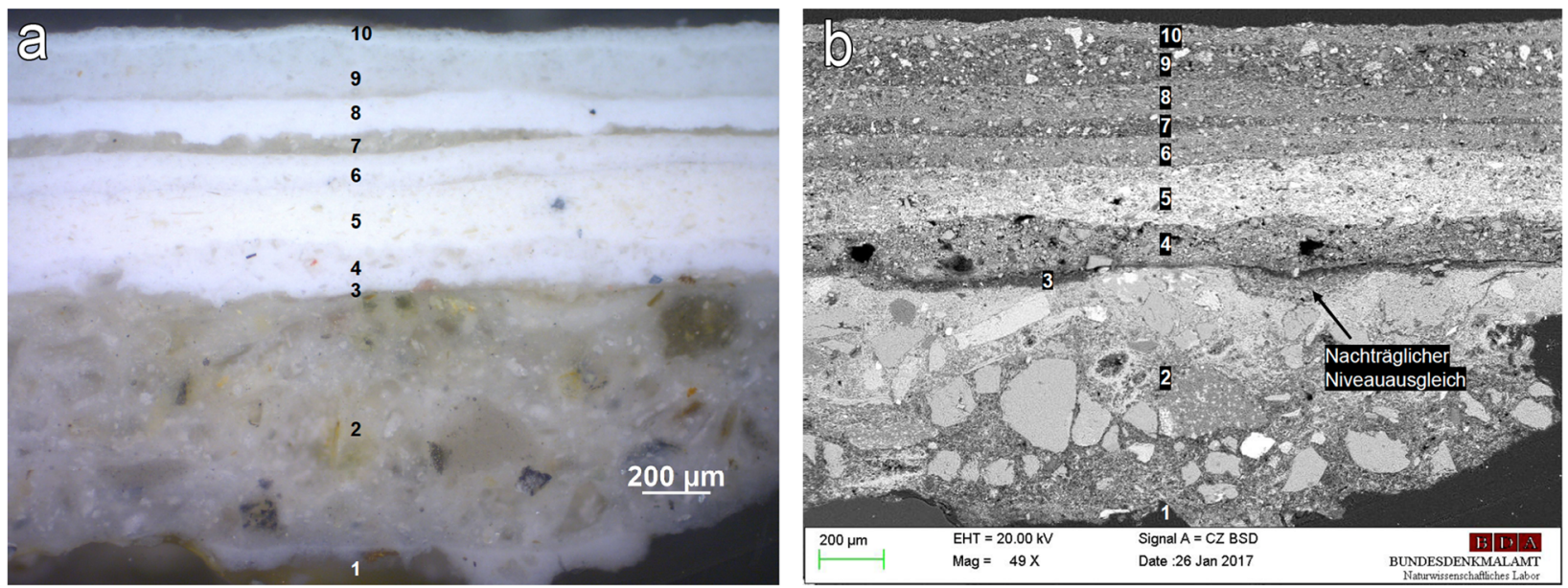

Fig. 19 Josef Frank and Oskar Wlach, Villa Beer in Vienna-Hietzing, 1930, living room, east wall, sample No.1, section and REM. 1: coarse plaster (bound with protein!); 2: Fine plaster: gypsum with silicate grains up to $300 \mu \mathrm{m}$, some dolomite and quartzite, compacted and smoothed surface; 3: primer ('Lösche') with protein (casein?); 4: yellowish-gray-white glue colour, fine sand (silicates) and chalk as filler and pigmentation, additionally an early form of titanium dioxide (anatase), no patina; 5: casein or tempera paint (?), some silicates, chalk and titanium dioxide (anatase), also gypsum ('Bolognese chalk') and zinc white (!); the impasto is softened compared to the first coat of paint, so applied thinner, colour tone clearly yellowish bright white. The other layers are later renovations (Source: Laboratory analysis: DI Dr. Robert Linke, Federal Heritage Authority)

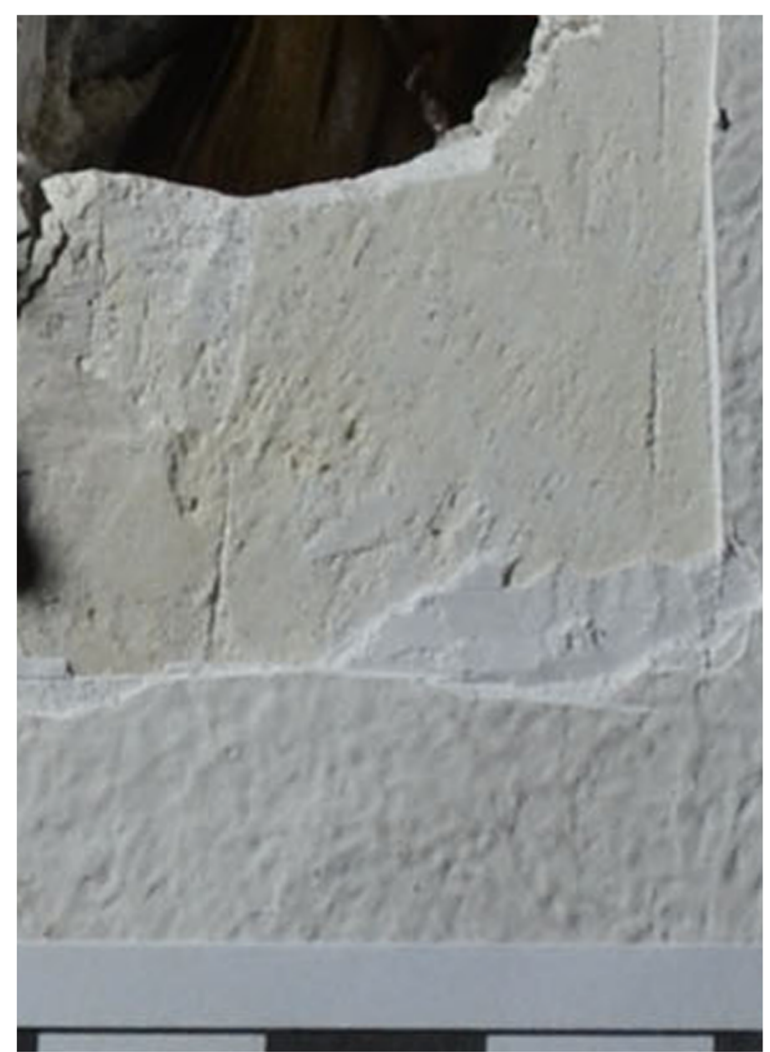

Fig. 20 Josef Frank und Oskar Wlach, Villa Beer in Wien-Hietzing (1930), music gallery, ceiling, probe 2017 in the area of the lamp, original yellowish white paint (see Fig. 19) (Source: HABEAS 2017) oil paint smoothed with precision, which approximates the material colour of metal. Only the entrance area was highlighted with bright colours: according to the analysis of Dr. Robert Linke, the Beer family's front door was painted 'Japanese red' (led chromate, colour term: 'Japanrot') (Fig. 18) (Born 1931, 363), bordered with slabs of 'Cipollino'/ Styra green marble, which is also known from buildings by Adolf Loos, e.g. the Michaelerhaus in Vienna.

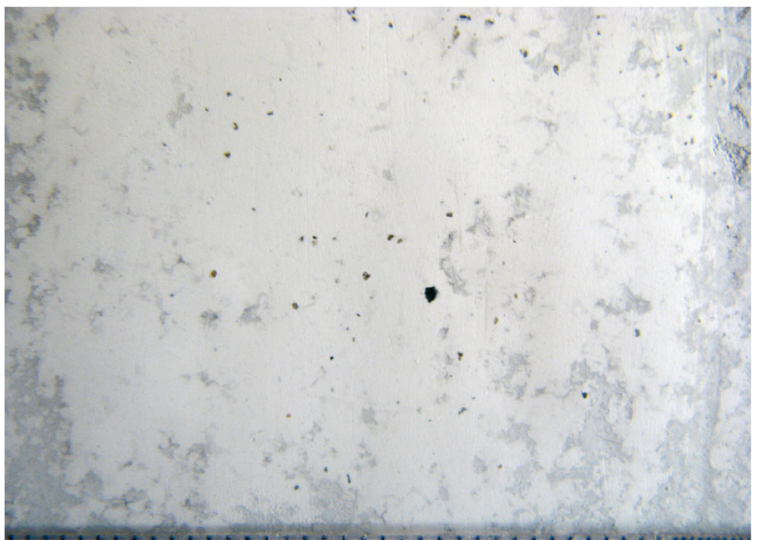

Fig. 21 Ludwig Mies van der Rohe and Lilly Reich, House Tugendhat, Brno, 1930, bedroom Grete Tugendhat, south-east wall, behind the closet (bottom edge photo approx. $4.5 \mathrm{~cm}$ ), sanding test of the original 'stucco lustro', with particles of pigmenting fine sand (Source: Ivo Hammer 2011) 


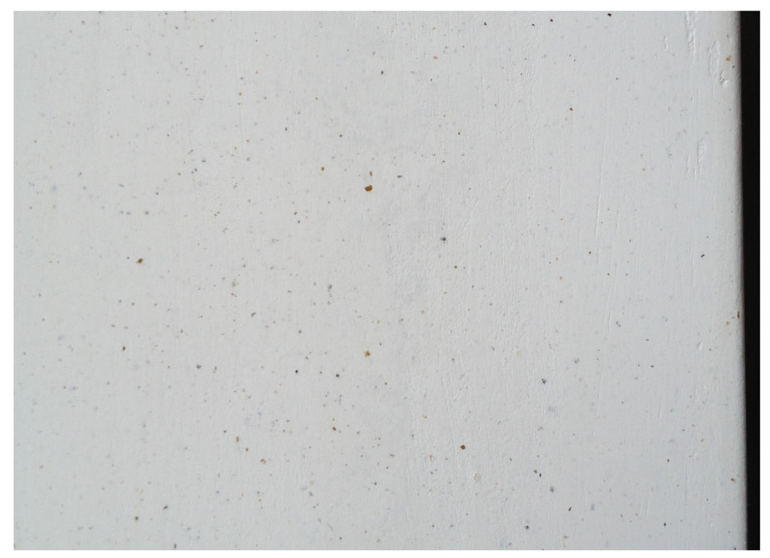

Fig. 22 Ludwig Mies van der Rohe and Lilly Reich, House Tugendhat, Brno, 1930, bedroom Fritz Tugendhat, 2011 reconstructed 'stucco lustro' (preservation by covering) (Source: Ivo Hammer 2013)

\section{Interior Wall surfaces}

The approximately $1.5 \mathrm{~cm}$ thick coarse plaster of the walls consists of a probably unwashed quartz sand (grain approx. 0-20 mm), with a dolomite component. The fact that the binder of coarse plaster, according to the analysis of Dr. Robert Linke, consists

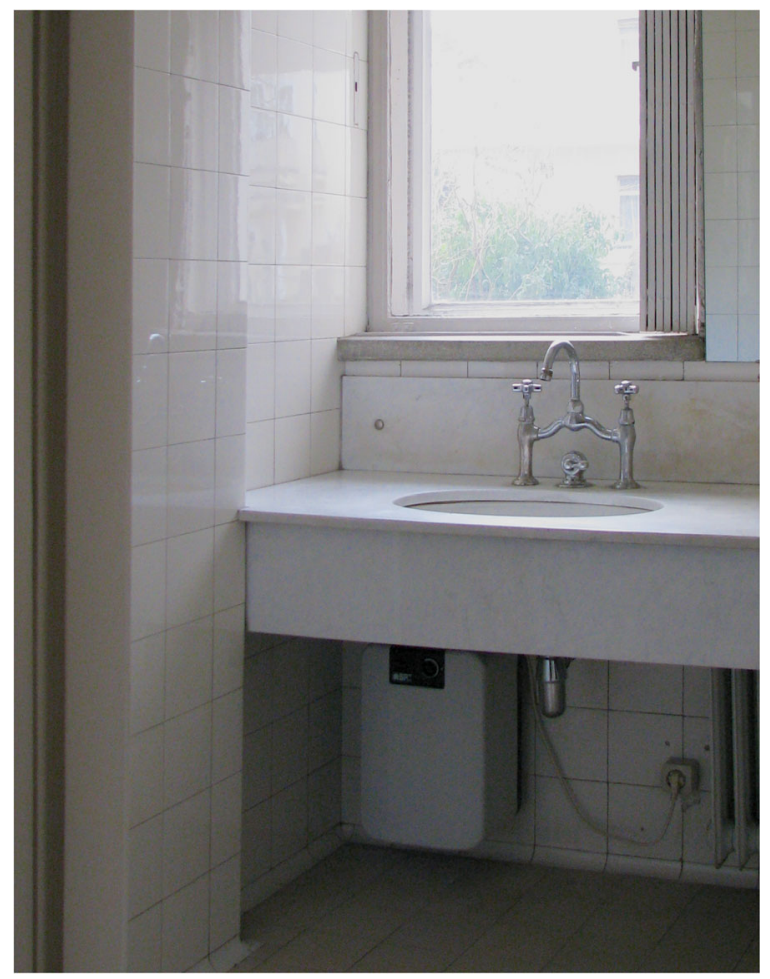

Fig. 23 Josef Frank and Oskar Wlach, Villa Beer in Vienna-Hietzing (1930), ground floor, entrance space of the toilet with largely preserved furnishings in finely graduated bright shades: carefully laid yellowish floor tiles and whitish yellow wall tiles (crimp joints), the washbasin with bright Carrara marble and original fixture (Source: Ivo Hammer 2017) essentially of protein (glucosine glue or casein) is probably exceptional. The partitions consist of traditional solid bricks ('half shoe' walls), partly of cement slag plates, reinforced with steel wire, partly also of gypsum slag plates. The ceilings are made of cast concrete (Ast-Mollins system) and suspended plaster girders made of reed mats and light metal grids ('hash grid'), with a cavity of approx. $26 \mathrm{~cm}$.

The careful preparation of the wall and ceiling surfaces consists of a stucco with finely smoothed gypsum, with gluten glue added and a considerable proportion of fine, silicate sand grains measuring up to approx. $300 \mu \mathrm{m}$, and also some dolomite. The grain colour of the fine silicates has the effect of giving an overall yellowish-white colour to the finely smoothed plaster. Casein paint was applied (at least partially in two layers) to a protein intermediate layer (casein or vegetable glue) with some oil ('tempera'), filled with chalk and gypsum (Bolognese 'chalk'), pigmented with fine silicates in silt grain size (perhaps also bright ochre pigments) and zinc white (Figs. 19 and 20). Robert Linke also verified the addition of an early type of titanium white, an opaque, white pigment, which had been manufactured in the USA and Norway since 1919 (KRONOS-titandioxide, anatase-modification, associated with $\mathrm{Si}$ und $\mathrm{Ca}){ }^{19}$ This was, as far as is known, the first use of this pigment in Austria, which was perhaps not mere coincidence. Josef Frank wanted the whiteness to appear as even, regular and 'pure' as possible, in keeping with his idea of the colour of interior walls, which he saw as being a neutral, nondominant background allowing a free choice of objects-and their colours - in the room: flowers, pictures, carpets, curtains and furniture. The use of the highly opaque titanium white is the technical correlate of the aesthetic intention of having a regular 'white' surface. The surface is relatively smooth; individual brush strokes ('impasto') are visible.

Nevertheless, the white-colour paint of the interior walls intended by the architect, and described in contemporary publications devoted to the Villa Beer, does not correlate with the physical evidence-the research team also considered the effects of aging and pollution. As a result of the presence of the aggregates described, the white paint of the walls and ceilings originally was yellowish, similar to that of the Tugendhat House (Figs. 21 and 22). However, all wall surfaces throughout the house were treated uniformly (Fig. 23) and-unlike in the case of the Tugendhat House-no

\footnotetext{
${ }^{19}$ http://materialarchiv.ch/\#/detail/984/titanweiss-pw-6, accessed 3.2.2018
} 
distinction was made between the servants' rooms and those of the family, in what perhaps is a reflection of the well-known social democratic attitude of Josef Frank. Also, other interior components, such as window frames, doors, fitted wardrobes and kitchen cabinets, which are made of various materials, were painted in a light yellowish hue of white with thoroughly smoothed surfaces (Fig. 24a, b, c). An exception is the spiral staircase in the service area: pale yellow column and pale yellow faces of the steps, the treads covered with green rubber (Fig. 24d). The remaining components, such as windows, doors, pillars, railings and radiators, were painted with oil or alkyd paint. The light yellowish-white paint is multi-layered and was manufactured with high-precision craftsmanship, comparable to that of the Tugendhat House (Hammer 2014).

Exceptions to this bright, aesthetic continuum of architectural surfaces are the fitted sideboard of the dining room and the library shelves, which, like the floors and benches, show the natural colour of the wood used, which was intensified by means of a transparent varnish; a technique found also on the metal surfaces of the Tugendhat House (Hammer 2014, 192). The inner wings of the box-type windows are painted on the outside with (slightly greenish) light grey, as are the exterior window frames. Marbles in different colours and brass decorate the fireplaces
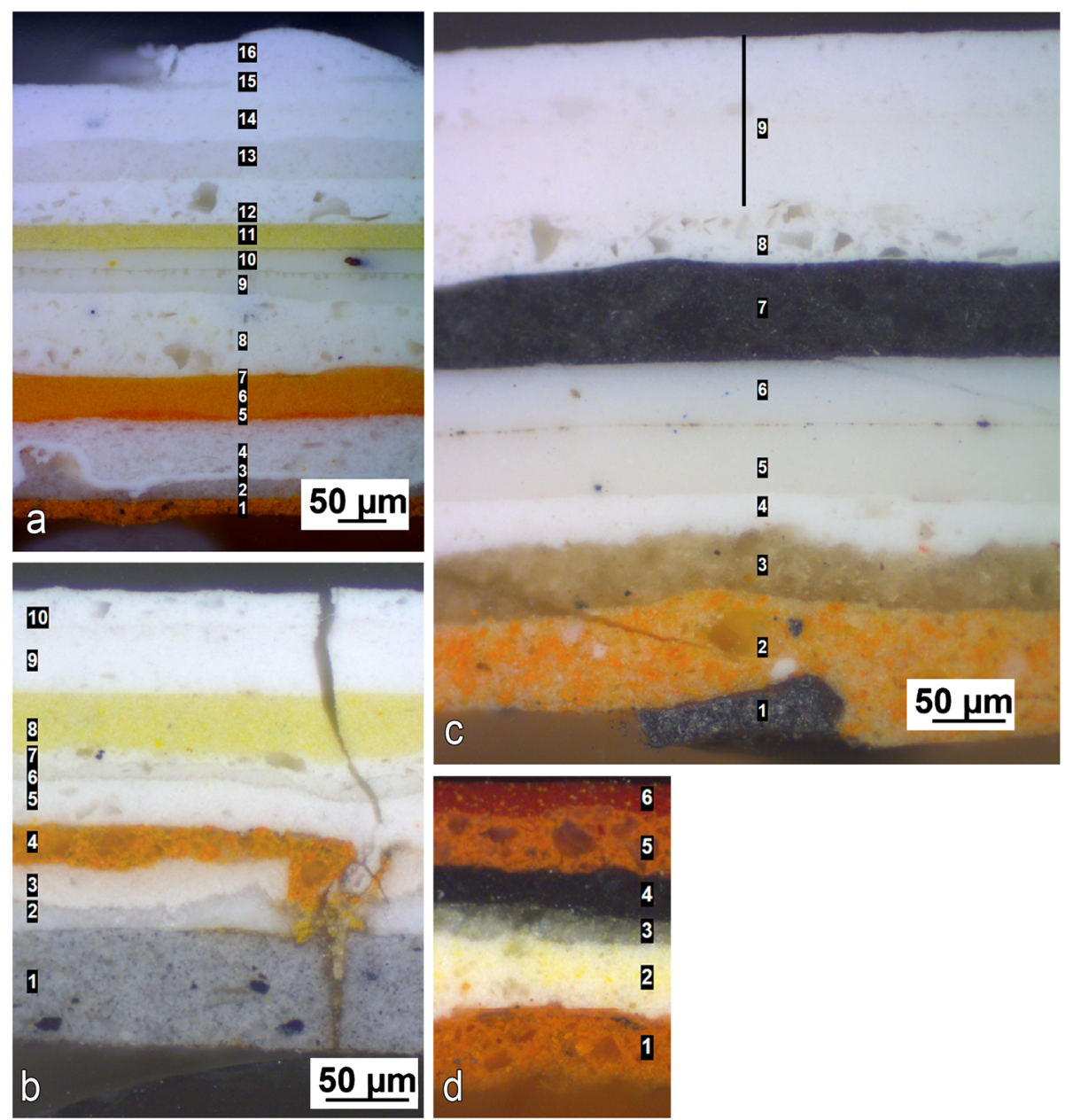

Figs. 24 Josef Frank and Oskar Wlach, Villa Beer in Vienna-Hietzing, 1930, paints on metal, sections of samples; binders: linseed oil or alkyd varnish. a: façade, main entrance, door frame metal, 'japan red', 1: minium primer with some iron oxide red, 2: primer: chalk, zinc white or zinc siccative / drip nose, 3: titanium white KRONOS (?), Chalk, 4: titanium white (KRONOS), Silicates (fine sand), 5: lead chromate as bichromate, red, 6: lead chromate like (5), orange red. 7-16: later coatings. b: library, window frame, outside, gray, 1: zinc white, lead white, leg black, fine silicates. Due to the fine silicates and the binder, the gray is a bit yellowish. c: Interior, mezzanine, railing metal, yellowish white, 1: tinder, 2: minium, zinc white, barite, 3: chalk, silicates, 4: barite, zinc white, 5: zinc white, patina (first version). d: mezzanine, service stairs, upright, light yellow, 1: minium, iron oxide, chalk, 2: barite, zinc white yellow ocher (original surface) (Source: Laboratory analysis: DI Dr. Robert Linke, Federal Heritage

Authority 2017) 


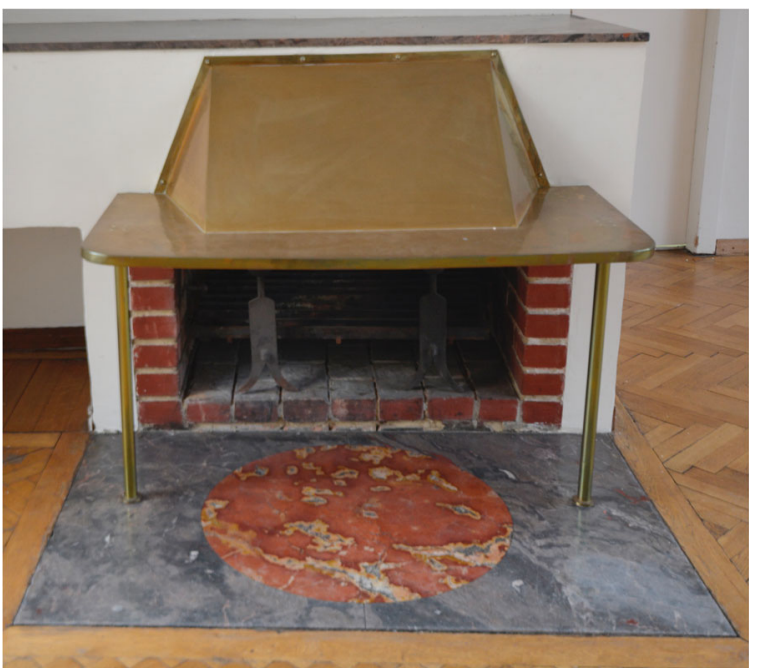

Fig. 25 Josef Frank and Oskar Wlach, Villa Beer in Vienna-Hietzing (1930), living room, fireplace with polished slabs of reddish limestone ('onyx' marble), crinoid limestone and brass chimney (Source: Ivo Hammer 2017)

of the hall, the living room and father's bedroom (Fig. 25). Green rubber-still in situ-covers the floor of some private rooms (Fig. 26). The bright, marblelike walls and ceilings in fact provided a noble, restrained background for the lively, colourful mobile furnishings that were planned for the house, such as curtains and furniture, and also for the flowers and other objects that surrounded the inhabitants in their daily living space.

\section{Conclusion}

We must rewrite the colour history of Modern Movement architecture. The 'white cubes' were never white. The notion of white as a metaphor for the 'Weltanschauung' of the Modern Movement, fixed as such in

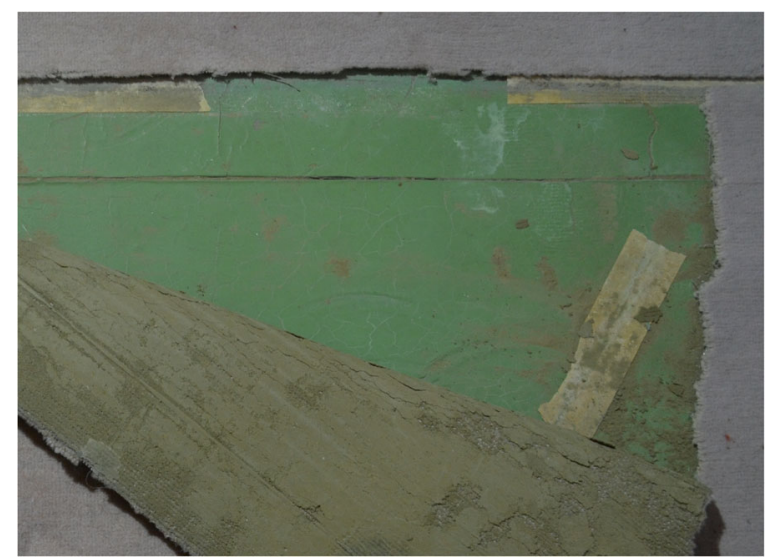

Fig. 26 Josef Frank and Oskar Wlach, House Beer in Vienna Hietzing (1930), attic, northern room with largely preserved green rubber flooring (Source: Ivo Hammer 2017) cultural memory due to black-and-white architectural photography and recorded in writing as intentional by the architects themselves, is superseded by the evidence provided by the colourful wealth of the actual works of architecture, including the material colour of white surfaces. The concept of the architects is not identical to the built result, as it is carried out by craftsmen using materials that were common at that time. Art is always more than just the intention of the artist, not least because of the inherent character-if not the 'stubbornness' of the materials used.

\section{Acknowledgements \\ The author acknowledges Dr. Robert Linke, Head of the Scientific Laboratory of the Federal Heritage Authority, Vienna, as author of the sample analysis for the Federal Monuments Authority of Austria. The author wishes to thank the MAK Museum Vienna, namely Christoph Thun-Hohenstein, Teresa Mitterlehner-Marchesani, Martina Kandeler-Fritsch and Sebastian Hack- enschmdt, the Federal Heritage Authority, namely Oliver Schreiber and Rob- ert Linke, the inspiring team of conservators-restorers, namely Alexandra Sagmeister, Lea Huck, Magdalena Schindler, Susanne Wutzig, architect Clau- dia Cavallar, Tano Bojankin and the Tongji University for their generous sup- port, and the Built Heritage editorial team and anonymous reviewers for their helpful comments.}

\section{Author's contributions}

The article was written by the author with support from two anonymous reviewers and the Built Heritage editorial team. The author read and approved the final manuscript prior to publishing.

\section{Funding}

The MAK (Museum of Applied Arts), Vienna and the Austrian Federal Heritage Authority funded the conservation-science study of the Villa Beer, Vienna/Austria.

\section{Availability of data and materials}

Not applicable.

\section{Competing interests}

Not applicable.

Received: 18 January 2020 Accepted: 3 April 2020

Published online: 04 September 2020

\section{References}

Achleitner, Friedrich. 1993. Wien 13.-18. Bezirk [Vienna 13-18 District]. Vol III/2 of the Österreichische Architektur im 20. Jahrhundert [Austrian Architecture in the 20th Century]. Vienna: Residenz Verlag.

Bojankin, Tano. 2008. "Das Haus Beer und seine Bewohner." [The Beer House and Its Residents.] In Josef Frank 1885-1967. Eine Moderne der Unordnung [Josef Frank 1885-1967. A modernity of disorder], edited by Meder Iris, 105-111. Salzburg: Verlag Anton Pustet.

Born, Wolfgang. 1931. "Ein Haus in Wien-Hietzing. Von Prof. Dr. Josef Frank, Dr. Oskar Wlach, (,Haus und Garten'). Wien." [House in Vienna-Hietzing by Prof. Dr. Josef Frank, Dr. Oskar Wlach, ('House and Garden'). Vienna.] Innendekoration (42) 10: 363-398.

Brinkmann, Vinzenz, and Andreas Scholl. 2010. Bunte Götter. Die Farbigkeit antiker Skulptur [Colourful gods. The colour of ancient sculpture]. München: Hirmer Verlag $\mathrm{GmbH}$.

Cerna, Iveta, and Ivo Hammer. 2008. Materiality. Brno: City Museum / Hildesheim: Hornemann Institute.

Dai, Shibing, and Yan Zhong. 2019. Sacrificial protection for architectural heritage conservation and preliminary approaches to restore historic fair-faced brick façades in China. Built Heritage 3 (1): 37-46.

Danzl, Thomas. 1999. "Restaurierung versus Konservierung? Zum restauratorischen Umgang mit historischen Putzen und Farbanstrichen an den Bauhausbauten in Dessau." [Restoration Versus Conservation? For the 
Restoration of Historical Plastering and Painting on the Bauhaus Buildings in Dessau.] Denkmalpflege in Sachsen-Anhalt 2: 100-112.

Danzl, Thomas. 2003. "Konservierung, Restaurierung und Rekonstruktion von Architekturoberflächen am Meisterhaus Muche/Schlemmer." [Conservation, Restoration and Reconstruction of Architectural Surfaces at the Muche/ Schlemmer Master House.] In Gropius. Meisterhaus Muche/Schlemmer. Die Geschichte einer Instandsetzung [Gropius. Meisterhaus Muche/Schlemmer. The Story of a Repair], edited by Gebeszler August, 152-181. Stuttgart/Zürich: Karl Krämer Verlag.

Frank, Josef. 1919. Das neuzeitliche Landhaus / The Modern Country House. Innendekoration, 30/11, Darmstadt, December 1919. =; (re-edition in German and English: Bojankin, Tano and Christopher Long, Iris Meder, eds. 2012. Josef Frank. Schriften in zwei Bänden / Josef Frank: Writings in Two Volumes, Wien/ Vienna: Metro Verlag: 146-153).

Frank, Josef. 1931. "Das Haus als Weg und Platz." [The House as a Way and Place]. Der Baumeister 8 (29): 316-323.

Frank, Josef. 2012. Josef Frank. Schriften in zwei Bänden / Josef Frank: writings in two volumes. Translated and edited by Bojankin Tano, Christopher Long and Iris Meder. Wien/Vienna: Metro Verlag. Gage, John. 1993. Colour and culture: practice and meaning from antiquity to abstraction. London: University of California Press

Haerdtl, Oswald. 1931. Una nuova casa di Josef Frank. [A New House of Josef Frank.] DOMUS 3 (43): 48-54. idem: Una casa privata degli architetti Josef Frank e Oscar Wlach. [A Private House of Architects Josef Frank and Oscar Wlach.] DOMUS 4 (44) (Milano): 28-30, 77.

Hammann, J. E. 1930. "Weiss, Alles Weiss. Von der Wertstellung der Farbe 'Weiss' in unserer Zeit." [White, all White. About the value of the colour 'white' in our time." Die Form. Zeitschrift für Gestaltende Arbeit. 5(5): 121-123.

Hammer, Ivo. 2003. Bedeutung historischer Fassadenputze und denkmalpflegerische Konsequenzen. Zur Erhaltung der Materialität von Architekturoberflache (mit Bibliographie und Liste von Konservierungsarbeiten). [Significance of Historical Facade Plasters and Consequences for Monument Preservation. Preserving the Materiality of the Architectural Surface (with Bibliography and List of Conservation Work).] ICOMOS Journals of the German National Committee XXXIX: 183-214.

Hammer, Ivo. 2004. Zur materiellen Erhaltung des Hauses Tugendhat in Brunn und anderer Frühwerke Mies van der Rohes. [For the Material Preservation of the Tugendhat House in Brunn and Other Early Works by Mies van der Rohe ] In Mies van der Rohe. Frühe Bauten. Probleme der Erhaltung - Probleme der Bewertung [Mies van der Rohe. Early constructions. Conservation Problems-Assessment Problems], edited by Cramer Johannes and Sack Dorothee, 14. Petersberg: Michael Imhof Verlag.

Hammer, Ivo 2008. Restauratorische Befundsicherung an frühmittelalterlichen Wandmalereien des Regnum Maravorum. [Restoration of Findings on Early Medieval Wall Paintings by the Regnum Maravorum.] In Frühmittelalterliche Wandmalereien aus Mähren und der Slowakei. Archäologischer Kontext und herstellungstechnische Analyse [Early Medieval Wall Paintings from Moravia and Slovakia. Archaeological Context and Manufacturing Analysis], edited by Daim, Falko and Pippal, Martina, 111-328. Innsbruck: Wagner.

Hammer, Ivo. 2010. Lime cannot be substituted! Remarks on the history of the methods and materials of painting and repairing historical architectural surfaces. In Colour on historical facades from the middle ages to modern times: history, research and conservation issues (proceedings of the international conference September 22-24, 2010, Królewski (astle), ed. Guttmeyer Karol, 317355. Warszawa: Biuro Stołecznego Konserwatora Zabytków.

Hammer, Ivo. 2011. Zur Restaurierung der Wandoberflächen des Innenraums der Ev. Pfarrkirche St. Marien in Salzwedel. Untersuchungen und Konzepte der HAWK Hildesheim. [Restoring the Wall Surfaces of the Interior of the Ev. Parish Church of St. Marien in Salzwedel. Investigations and Concepts of the HAWK Hildesheim.] Denkmalpflege in Sachsen-Anhalt, Zeitschrift des Landesamtes für Denkmalpflege und Archäologie Sachsen-Anhalt 2 (10): 4463.

Hammer, Ivo. 2012. The material is polychrome! From interdisciplinary study to practical conservation and restoration: the wall surfaces of the Tugendhat house as an example. In La conservazione delle policromie nell'architettura del XX secolo / Conservation of Colour in 20th Century Architecture, ed. Jean Giacinta, 234-249. Lugano: Nardini Editore.

Hammer, Ivo. 2014. Materiality: history of the Tugendhat house 1997-2012. Conservation-science study and restoration. In Tugendhat House. Ludwig Mies van der Rohe, ed. Hammer-Tugendhat Daniela, Hammer Ivo, and Tegethoff Wolf, 162-233. Basel: Birkhauser/de Gruyter.
Haus, Andreas. 2015. "Schwarz-Weiss. Architekturfotografie des 'Neuen Bauens'." [Black-and-White. Architectural Photography of the 'New Building'.]. In Schwarz-Weiß als Evidenz: with black and white you can keep more of a distance, ed. Monika Wagner and Helmut Lethen, 171-190. New York: Campus Verlag.

Hitchcock, Henry Russel, and Philipp Johnson. 1932. The international style: architecture since 1922. New York: MoMA.

Koller, Manfred. 1989. Denkmal-Pflege mit 'Opferschichten'. [Heritage Preservation with Sacrificial Layers]. In Österreichische Zeitschrift für Kunst und Denkmalpflege (ÖZKD) XLIII, 1989 (Wien): 48-52.

Le Corbusier. 1925a. L'art décoratif d'aujourd'hui [Today's decorative art]. Paris: Éditions Vincent, Fréal \& Cie.

Le Corbusier. 1925b. Almanach d'architecture modern [Almanac of modern architecture]. Paris: Les editions G. Crès et Cie.

Le Corbusier. 1935. Fuvre complete [Complete Work]. Vol. 1, 1910-1929, Zurich 1935.

Metzger-Szmuk, Nitza. 2008. The Plaster in the 'White City' of Tel Aviv. History, Technologies and Dilemmas. In Materiality, edited by Iveta Černá and Ivo Hammer, 68-72. Brno / Hildesheim: Brno City Museum and Hornemann Institute.

Ott-Wodni, Marlene. 2015. Josef Frank 1885-1967. Raumgestaltung und Möbeldesign. Wien: Böhlau.

Reichwald, Helmut F. 2008. Surfaces and colour treatment of the interior and exterior of the double house by Le Corbusier and Pierre Janneret. In Materiality, ed. Iveta Černá and Ivo Hammer, 58-66. Brno / Hildesheim: Brno City Museum and Hornemann Institute.

Rückert, Otto. 1931. Handwerk und neues Bauen. [Crafts and new building.] Die Form. Zeitschrift für Gestaltende Arbeit. no. 6, 1931 (Berlin): 201-206.

Rüegg, Arthur. 2015. Polychromie architecturale: Le Corbusiers Farbenklaviaturen von 1931 und 1959 [Polychromy Architecturale: Le Corbusier's colour keyboards from 1931 and 1959]. Basel: Birkhauser.

Strässle, Thomas, Christoph Kleinschmidt, Johannes Mohs 2013. Das Zusammenspiel der Materialien in den Künsten. Theorien. Praktiken. Perspektiven. Bielefeld: transcript.

Thun-Hohenstein, Christoph, Hermann Czech, and Sebastian Hackenschmidt. 2016. Josef Frank: against design - the anti-formalist oeurre of the architect. Basel: Birkhäuser Verlag.

Tsiomis, Yanis. 2012. "Le Corbusier, L'Art décoratif d'aujourd'hui et, la loi du ripolin." [Le Corbusier, The Decorative Art of Today and, The Law of the Ripolin.] In L'année 1925. L'esprit d'une époque [The Year 1925. The Spirit of an Era], edited by Boucharenc Myriam and Leroy Claude, 63-79. Paris: Presses universitaires de Paris Nanterre.

Wagner, Monika. 2008. Berlin urban spaces as social surfaces: machine aesthetics and surface texture. Representations 102 (1): 53-75.

Wagner, Monika. 2018. Marmor und Asphalt. Soziale Oberflächen im Berlin des 20. Jahrhunderts [Marble and Asphalt. Social Surfaces in Berlin in the 20th Century]. Berlin: Klaus Wagenbach Verlag.

Wilk, Johanna. 2015. "Das Haus Beer - die Bestandsaufnahme einer Innenausstattung aus den 1930er Jahren." [The Beer house-the inventory of an interior from the 1930s.] In Collection Care. Sammlungspflege, edited by Krist Gabriela, 223-234. Vienna/Cologne/Weimar: Böhlau Verlag.

\section{Publisher's Note}

Springer Nature remains neutral with regard to jurisdictional claims in published maps and institutional affiliations. 